\title{
Achene Morphology and Anatomy of Clematis L. (Ranunculaceae) in Korea and Its Taxonomic Implications
}

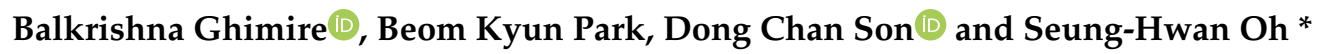 \\ Division of Forest Biodiversity, Korea National Arboretum, Pocheon 11186, Korea; ghimire2ab@gmail.com (B.G.); \\ kashpbk@korea.kr (B.K.P.); sdclym@korea.kr (D.C.S.) \\ * Correspondence: oshwan@korea.kr
}

Received: 22 July 2020; Accepted: 23 September 2020; Published: 28 September 2020

check for updates

\begin{abstract}
Clematis, a widely distributed genus in Ranunculaceae, is one of the most difficult groups of taxa in the family from a taxonomic point of view. A comprehensive study on achene morphology and the anatomy of 19 taxa of Clematis from Korea was carried out using scanning electron and light microscopy to evaluate the taxonomic significance of achene characters. Clematis achenes are elliptical, obovate or fusiform in shape, light yellow or brown to black in color and completely or sparsely covered with hairs. The permanent style is elongated and plumose in all the studied taxa except C. brachyura. We found that the size, indument, permanent style, surface sculpture, shape in cross-section, and nature and thickness of the exocarp, and endocarp were valuable achene features for species delimitation and may contribute to the unraveling of the taxonomic problems in the genus Clematis. One-way analysis of variance (ANOVA) indicated that the quantitative achene variables among the species were highly significant $(p<0.001)$. Principal component analyses based on seven quantitative characters and UPGMA (unweighted pair-group method with arithmetic mean) analysis based on seven quantitative and 18 qualitative characters also signify the utility of achene features for taxonomic discriminations of the Clematis taxa within the genus. Similar to other morphological characters in the genus Clematis, achene morphological and anatomical characters with the limited taxonomic value alone cannot be expected to resolve the infrageneric relationships but certain achene features combined with other morphological features could be useful as an alternative means of determining the infrageneric relationships within the genus.
\end{abstract}

Keywords: Achene characters; Clematis; Ranunculaceae; taxonomic relationship

\section{Introduction}

Clematis L. is one of the largest genera in Ranunculaceae with about 280-350 species [1-3] most of which are woody or herbaceous vines, but a few are shrubs, subshrubs, or erect perennial herbs. The genus is widely distributed throughout the world but with considerable diversity in temperate and subtropical regions of the Northern Hemisphere, especially eastern Asia. China, which is believed to be the center of diversity of the genus, alone has 147 species, of which 93 are endemic [4-6]. Its remarkable climatic plasticity, showy flowers, and easy hybridization process make Clematis a horticulturally important genus that is widely cultivated in Europe, North America, and East Asian countries [7].

With respect to morphology-based monographs, Clematis has been subjected to several infrageneric classifications [1,3-5,8,9]. Tamura [1] divided Clematis into four subgenera including 16 sections some of which were subdivided into subsections and series. Grey-Wilson [4] later grouped 297 species in nine subgenera, 16 sections, and 26 subsections whereas Johnson [5] recognized 18 sections and 36 subsections 
covering 325 species of the genus. Based on analyses of the various morphological and palynological characters of 345 Clematis species, Wang and $\mathrm{Li}$ [3] more recently purposed a system of classification establishing four subgenera two similar to those of Tamura [1] and two new subgeneric names within the genus, which are further divided into 15 sections and numerous subsections and series. These three classification systems largely agree with one another on species separations but vary in infrageneric discrimination. In this study, we follow Johnson [5,9] for infrageneric classification and Lee [10], Chang et al. [11], the Korea National Arboretum [12], and Kim [13] for species delimitations.

According to a comprehensive classification of Ranunculaceae by Tamura [2], Clematis belongs to the tribe Anemoneae of the subfamily Ranunculoideae. Furthermore, within Anemoneae the genus has been considered to be closely related to two small genera Archiclematis (Tamura) Tamura and Naravelia DC., which are together grouped in the subtribe Clamatidinae [2]. Morphologically, these three genera share a similar climbing habit and persistent hairy style in their mature achenes. The only feature that distinguishes the monotypic genus Archiclematis within the subtribe is the alternate leaf phyllotaxy. However, the close affinity of Archiclematis alternata (Kitam. and Tamura) Tamura-including similar flower morphology - with the subgenus Viorna Gray in Clematis led Wang and Li [3], Grey-Wilson [4], Wang and Bartholomew [6], and Johnson [9] to include this species within Clematis.

Several studies considering various morphological, anatomical, palynological, and cytological characters of Clematis have been performed [1-4,9,14-25]. Unfortunately, none of these morphological characters seem to provide enough information to resolve the infrageneric ambiguity of this large genus. As morphological and anatomical characters are subject to varied interpretations, the accurate infrageneric classification of this large genus, especially at the sectional level remains notoriously difficult. Due to this complex morphological variation within the genus and the different characters underlined in each system, the existing classifications systems for the genus diverge from one other $[1,3-5,8,9]$. Several molecular phylogenetic studies have also been performed in recent years [26-31] mostly supporting the monophyly of Clematis with clear suggestions for the retention of Archiclematis and Naravelia in a separate section within Clematis $[27,29,30]$. Unfortunately, the phylogenetic hypotheses supported by the morphological data were vastly incompatible with molecular hypotheses. Lehtonen et al. [31] recently studied 132 taxa of Clematis to clarify the infrageneric relationships within the genus by optimizing the phenotypic and molecular data. Their results [31] do not agree with the previous subgeneric classifications of the genus due to poor support, short branch lengths and a lack of morphologically designated units. However, they obtained 12 stable and well supported clades conceptually matching the sectional divisions of Johnson [5,9].

Fruit and seed morphological characters have contributed useful phylogenetic data and are thus frequently used to discriminate the taxa in different taxonomic ranks. In particular, the surface sculpture of fruits, seeds or a combination of both provided a valuable reference for phylogenetic and/or systematic studies [32-40]. Different researchers have performed fruit and seed morphological studies emphasizing the taxonomic value of several Ranunuculaceae taxa [14,39,41-52] but studies pertaining to the fruit morphology and anatomy of Clematis are entirely absent in previous reports. Previous molecular phylogenetic studies $[27,29]$ concluded that many morphological features in this genus traditionally considered to be useful for determining systematic relationships were highly homoplasious and not phylogenetically indicative. However, Lehtonen et al. [31] believed that the careful re-analysis of characters may facilitate a much better character coding and understanding of morphological evolution in Clematis.

There is a longstanding argument among plant taxonomists regarding the exact number of species and taxonomic nomenclature of the Clematis taxa in Korea. Nakai [53] reported 21 species and 14 varieties of Clematis in a synoptical sketch of Korean flora but Lee [54] later described 16 species, 11 varieties, and five forma in the genus. Before Moon et al. [55], who claimed a new record of $C$. takedana Makino in Korea, the Korea National Arboretum and The Plant Taxonomic Society of Korea [56] included 24 taxa of Clematis in the synonymic list of vascular plants in Korea. Despite the new record of C. takedana claimed by Moon et al. [55], the origin and distribution of this species are doubtful, and not 
all taxonomists have accepted this taxon [10-13]. In the book New Flora of Korea, Lee [8] described 18 taxa including C. taeguensis Y. Lee, which was first described by Lee [57], whereas Chang et al. [8] only described 12 species and three varieties in the Illustrated Encyclopedia of Fauna \& Flora of Korea. Clematis taeguensis was not included in the Illustrated Encyclopedia of Fauna \& Flora [10] and The Flora of Korea [13] although it has been recognized as an accepted species name in the World Flora Online (WFO) [58]. The Korea National Arboretum [12] recently listed 17 species and five varieties of Clematis in the Checklist of Vascular Plants in Korea whereas Kim [13] described 13 species and seven varieties within the genus in The Flora of Korea. After a careful review of Lee [10], Chang et al. [11], the Korea National Arboretum [12], and Kim [13] we have included 16 species and three varieties, taking $C$. takedana as an individual species.

In this study, we provide a comprehensive investigation of achene morphology and the anatomy of 19 Clematis taxa distributed in Korea. The primary objective of this study was to investigate the detailed structure of achene morphology and the anatomy of the included taxa and evaluate the applicability of achene features for species discrimination. The results are also discussed in relation to the infrageneric classification of the genus.

\section{Materials and Methods}

\subsection{Specimens}

More than 550 achenes from 19 taxa representing eight sections [5,9] of Clematis were investigated. The names of the investigated species with their infrageneric classifications and voucher numbers are listed in Table 1. The voucher specimens are deposited in the herbarium of Korea National Arboretum (KNA). 
Table 1. Name of taxa with voucher number and collection information.

\begin{tabular}{|c|c|c|}
\hline Taxon & Locality & Voucher No. \\
\hline C. apiifolia DC. & Mt. Sinbul, Icheon-ri, Sangbuk-myeon, Ulju-gun, Ulsan, Korea & Sinbulsan-190911-001 \\
\hline C. brevicaudata DC. & Unchi-ri, Sindong-eup, Jeongseon-gun, Gangwon-do, Korea & Unchiri-191007-001 \\
\hline C. trichotoma Nakai & Mt. Sinbul, Icheon-ri, Sangbuk-myeon, Ulju-gun, Ulsan, Korea & Sinbulsan-190911-001 \\
\hline C. taeguensis Y. Lee & Gyuram-ri, Jeongseon-eup, Jeongseon-gun, Gangwon-do, Korea & Gyuramri-190818-001 \\
\hline C. hexapetala Pall. & Ho-ri, Palbong-myeon, Seosan-si, Chungcheongnam-do, Korea & Hori-190809-001 \\
\hline C. terniflora DC. & Jukpo-ri, Dolsan-eup, Yeosu-si, Jeollanam-do, Korea & Dolsando-191004-002 \\
\hline C. terniflora var. mandshurica (Rupr.) Ohwi & Namhansanseong Fortress, Sanseong-ri, Namhansanseong-myeon, Gwangju-si, Gyeonggi-do, Korea & Namhansanseong-190809-001 \\
\hline C. heracleifolia DC. & Sihwa Lake, Munho-ri, Namyang-eup, Hwaseong-si, Gyeonggi-do, Korea & Sihwaho-190921-016 \\
\hline C.urticifolia Nakai ex Kitag. & Mt. Gariwang, Sugam-ri, Bukpyeong-myeon, Jeongseon-gun, Gangwon-do, Korea & Gariwangsan-191007-001 \\
\hline C. takedana Makino & Sihwa Lake, Munho-ri, Namyang-eup, Hwaseong-si, Gyeonggi-do, Korea & Sihwaho-190921-001 \\
\hline C. patens C.Morren \& Dence. & Mt. Johang, Samsong-ri, Cheongcheon-myeon, Goesan-gun, Chungcheongbuk-do, Korea & Johangsan-170831-049 \\
\hline C. brachyura Maxim. & Seondol, Bangjeol-ri, Yeongwol-eup, Yeongwol-gun, Gangwon-do, Korea & Seondol-190719-001 \\
\hline C. serratifolia Rehder & Gasong-ri, Dosan-myeon, Andong-si, Gyeongsangbuk-do, Korea & Gasongri-191007-001 \\
\hline C. fusca var. fusca Turcz. & Mt. Cheongtae, Sapgyo-ri, Dunnae-myeon, Hoengseong-gun, Gangwon-do, Korea & Cheongtaesan-190819-001 \\
\hline C. fusca var. flabellata (Nakai) J. S. Kim & Eundae-bong, Gohan-ri, Gohan-eup, Jeongseon-gun, Gangwon-do, Korea & Eundaebong-190818-001 \\
\hline C. fusca var. violacea Maxim. & Mt. Baekhwa, Mawon-ri, Mungyeong-eup, Mungyeong-si, Gyeongsangbuk-do, Korea & Baekhwasan-150707-007 \\
\hline C. calcicola J. S. Kim & Mt. Deokhang, Daei-ri, Singi-myeon, Samcheok-si, Gangwon-do, Korea & Deokhangsan-190818-001 \\
\hline C. koreana Kom. & Mt. Hambaek, Gohan-ri, Gohan-eup, Jeongseon-gun, Gangwon-do, Korea & Hambaeksan-190818-001 \\
\hline C. ochotensis (Pall.) Poiret & Mt. Gariwang, Sugam-ri, Bukpyeong-myeon, Jeongseon-gun, Gangwon-do, Korea & Gariwangsan-190819-007 \\
\hline
\end{tabular}




\subsection{Light Microscopy}

At least three to five achenes of each taxon were used for microtome sectioning according to the following procedure. Mature achenes were dehydrated through an ethanol series $(50,70,80,90$, 95 and 100\%). After complete dehydration, the achenes were infiltered with ethanol/Technovit combinations (3:1, 1:1, 1:3, and 100\% Technovit) and then embedded in Technovit 7100 resin. The embedded materials were cut into serial sections of 4-6 $\mu \mathrm{m}$ thickness using a Leica RM2255 rotary microtome (Leica Microsystems $\mathrm{GmbH}$, Wetzlar, Germany) with disposable blades, stuck onto a slide glass, and dried using an electric slide warmer for $12 \mathrm{~h}$. The dried slides were stained with $0.1 \%$ Toluidine Blue ' $\mathrm{O}$ ' for 60-90 s, rinsed with water and again dried with a slide warmer for at least $6 \mathrm{~h}$ to remove water. The stained slides were then mounted with Entellan (Merck Co., Darmstadt, Germany) and permanent slides were prepared which were examined under a Leica DM3000 LED (Leica Microsystem, Wetzlar, Germany). Photomicrographs were taken with a scientific CMOS camera. Multiple image alignment was performed using Photoshop CS for Windows 2010. A Hirox 3D microscope (Hirox, Tokyo, Japan) was used to measure the quantitative features of the pericarp, and endocarp and the diameter of the cross section. The mean values and standard deviations of each feature were calculated from the measurements taken from the same species but different samples.

\subsection{Scanning Electron Microscopy}

The achenes were dried and desiccated thus no special pre-treatment procedures were applied in preparation for scanning electron microscopy (SEM). Before SEM imaging the achenes were immersed in 100\% ethanol and were sputter coated with gold in a KIC-IA COXEM Ion-Coater (COXEM. Co., Ltd., Daejeon, Korea). SEM imaging was carried out with a COXEM EM-30 PLUS+ scanning electron microscope (COXEM) at $20 \mathrm{kv}$, at the seed testing laboratory of the Korea National Arboretum. The scale bars in the images were added manually.

\subsection{Morphometry and Data Analysis}

Approximately 400 achenes were used for morphometric measurements. Digital images of whole achenes were taken with a Leica DFC420 C multifocal camera attached to a Leica MZ16 FA microscope (Leica Microsystems). The lengths and widths of randomly selected at least 15 achenes from each taxon were measured using Leica LAS V3.8 for Windows (Supplementary File S1). The biometric data were statistically analyzed using SPSS (IBM SPSS Statistics for Windows Version 20.0., IBM Corp., Armonk, NY, USA). For each achene variable, one-factor analysis of variance (ANOVA) was used to examine differences in the means among the included species. Principal component analysis (PCA) based on means of seven quantitative (excluding ratios) achene characters and cluster analysis based on a paired group (UPGMA) of seven quantitative and 18 qualitative characters, which are categorized and coded with binary and/or multistate character states based on the standardized log10 transformations of mean values, were also performed to understand the significance of achene features for species delimitations using the statistical program PAST ver. 4.02 [59]. The character states and their coding are provided in Supplementary File S2.

\section{Results}

A selected stereomicroscopic image of a single achene, a scanning electron microscopic image of the achene surface, and light microscopic images of pericarp structure are shown in Figure 1, Figure 2, Figure 3, Figure 4, Figure 5, Figure 6, Figure 7. The morphological features of the achenes and anatomical features of the pericarp are comprehensively described below. 

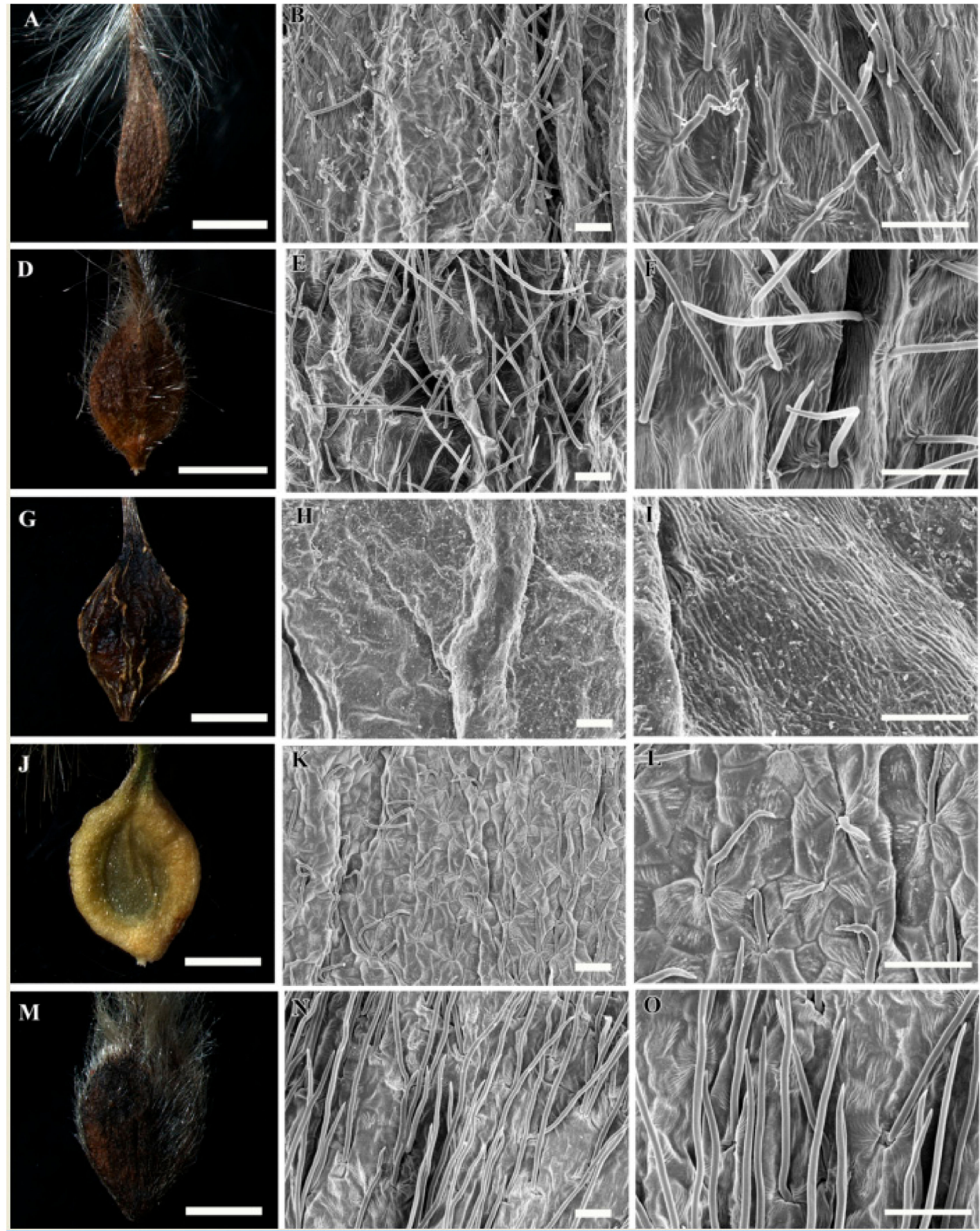

Figure 1. Stereomicroscopic and scanning electron microscopic micrographs of achenes of Clematis. (A-C) C. apiifolia. (D-F) C. brevicaudata. (G-I) C. trichotoma. (J-L) C. taeguensis. (M-O) C. hexapetala. Scale bars: $2 \mathrm{~mm}(\mathbf{A}, \mathbf{D}, \mathbf{G}, \mathbf{J}, \mathbf{M}) ; 100 \mu \mathrm{m}(\mathbf{B}, \mathbf{C}, \mathbf{E}, \mathbf{F}, \mathbf{H}, \mathbf{I}, \mathbf{K}, \mathbf{L}, \mathbf{N}, \mathbf{O})$. 

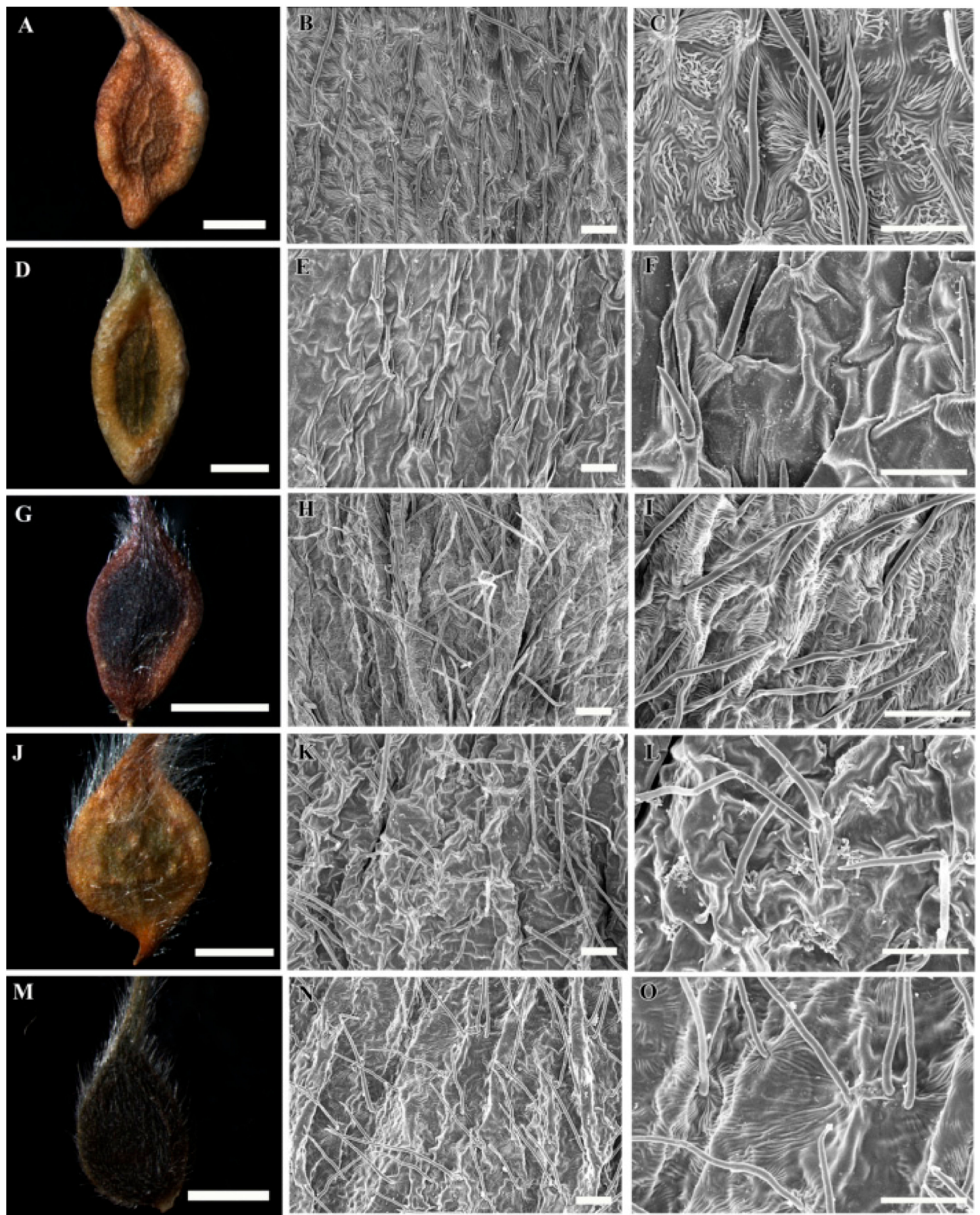

Figure 2. Stereomicroscopic and scanning electron microscopic micrographs of achenes of Clematis. (A-C) C. terniflora. (D-F) C. terniflora var. mandshurica. (G-I) C. heraclefolia. (J-L) C. urticifolia. (M-O) Clematis takedana. Scale bars: 2 mm (A,D,G,J,M); $100 \mu \mathrm{m}(\mathbf{B}, \mathbf{C}, \mathbf{E}, \mathbf{F}, \mathbf{H}, \mathbf{I}, \mathbf{K}, \mathbf{L}, \mathbf{N}, \mathbf{O})$. 

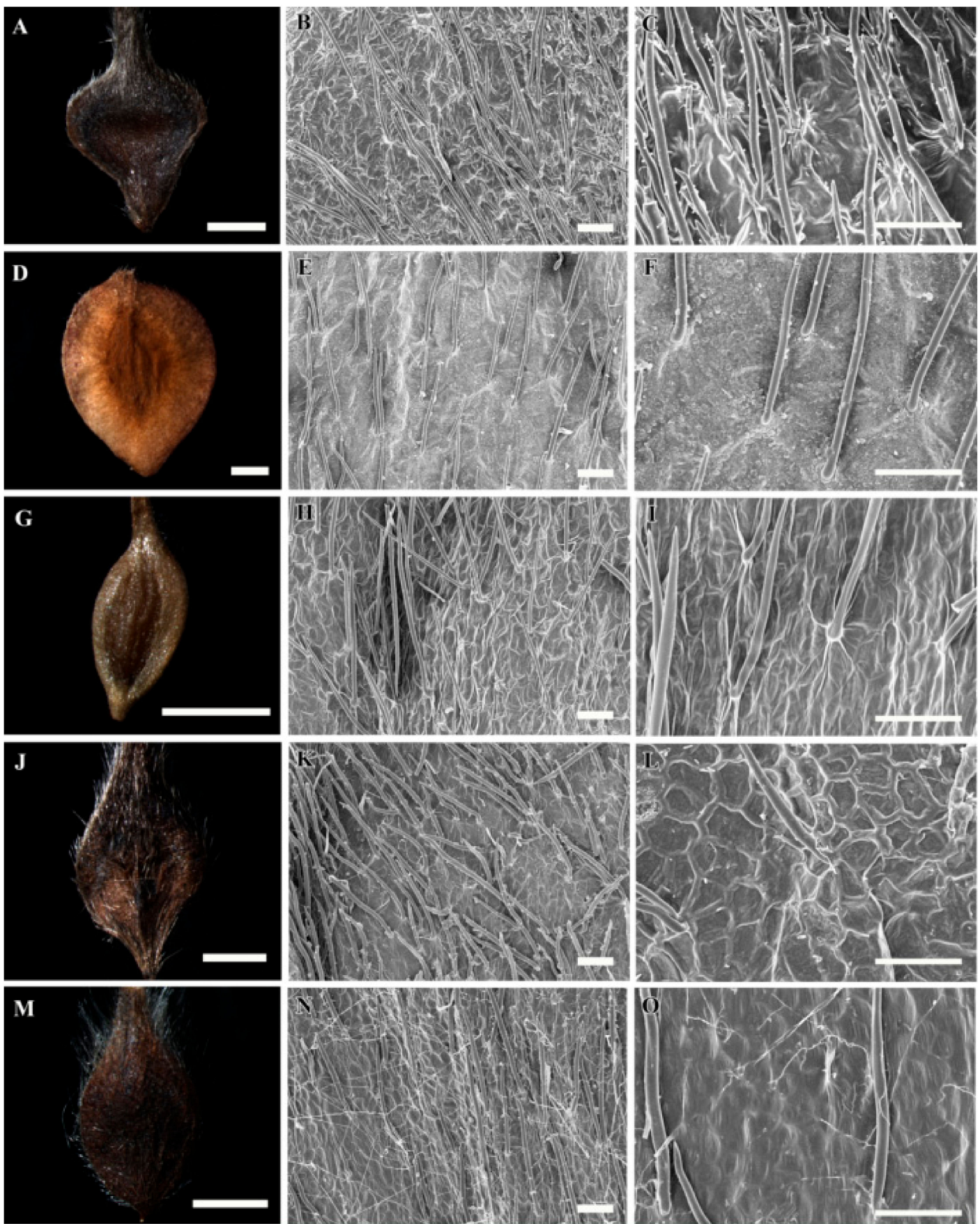

Figure 3. Stereomicroscopic and scanning electron microscopic micrographs of achenes of Clematis. (A-C) C. patens. (D-F) C. brachyura. (G-I) C. serratifolia. (J-L) C. fusca var. fusca. (M-O) C. fusca var. flabellata. Scale bars: $2 \mathrm{~mm}(\mathbf{A}, \mathbf{D}, \mathbf{G}, \mathbf{J}, \mathbf{M}) ; 100 \mu \mathrm{m}(\mathbf{B}, \mathbf{C}, \mathbf{E}, \mathbf{F}, \mathbf{H}, \mathbf{I}, \mathbf{K}, \mathbf{L}, \mathbf{N}, \mathbf{O})$. 

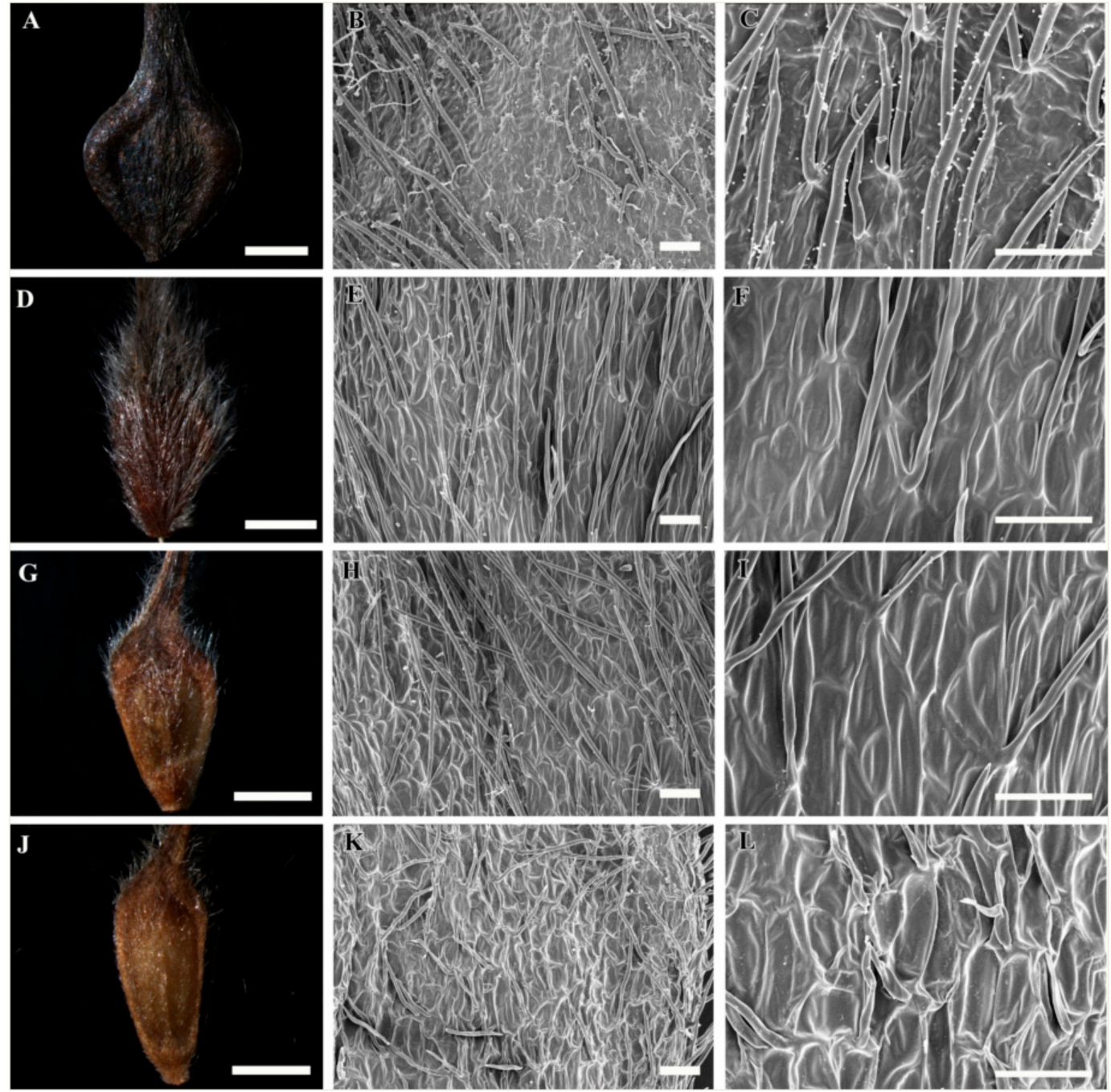

Figure 4. Stereomicroscopic and scanning electron microscopic micrographs of achenes of Clematis. (A-C) C. fusca var. violacea. (D-F) C. calcicola. (G-I) C. koreana. (J-L) C. ochotensis. Scale bars: $2 \mathrm{~mm}$ $(\mathbf{A}, \mathbf{D}, \mathbf{G}, \mathbf{J}) ; 100 \mu \mathrm{m}(\mathbf{B}, \mathbf{C}, \mathbf{E}, \mathbf{F}, \mathbf{H}, \mathbf{I}, \mathbf{K}, \mathbf{L})$. 
A
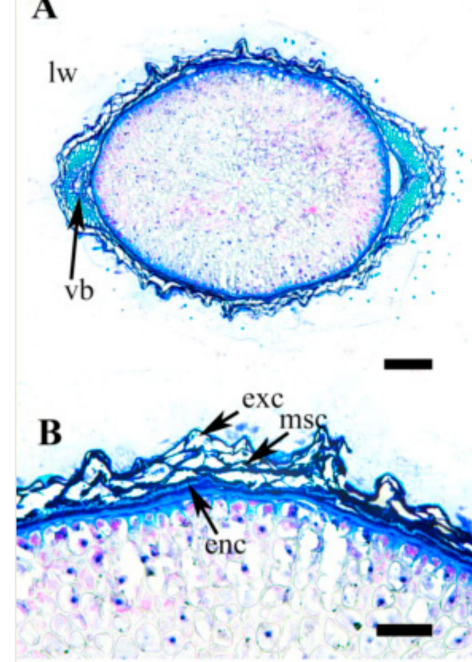

G

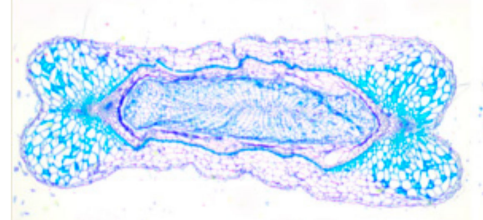

C

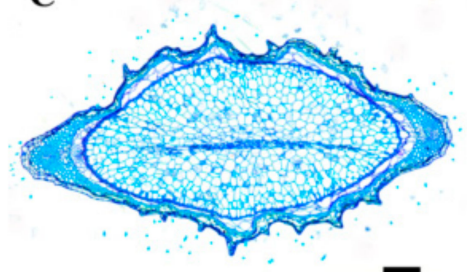

$\mathbf{E}$

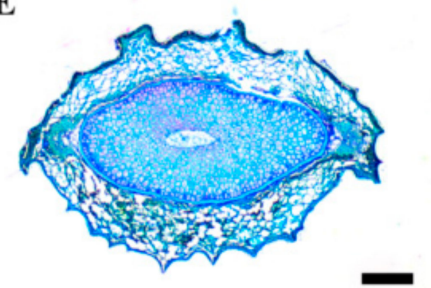

D

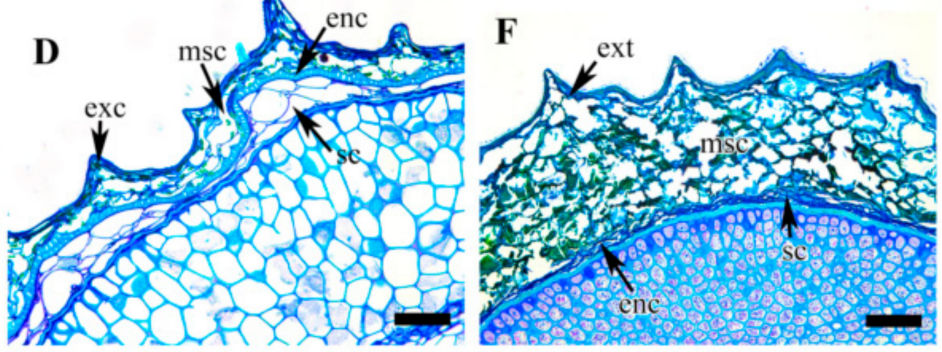

I

$\mathbf{K}$
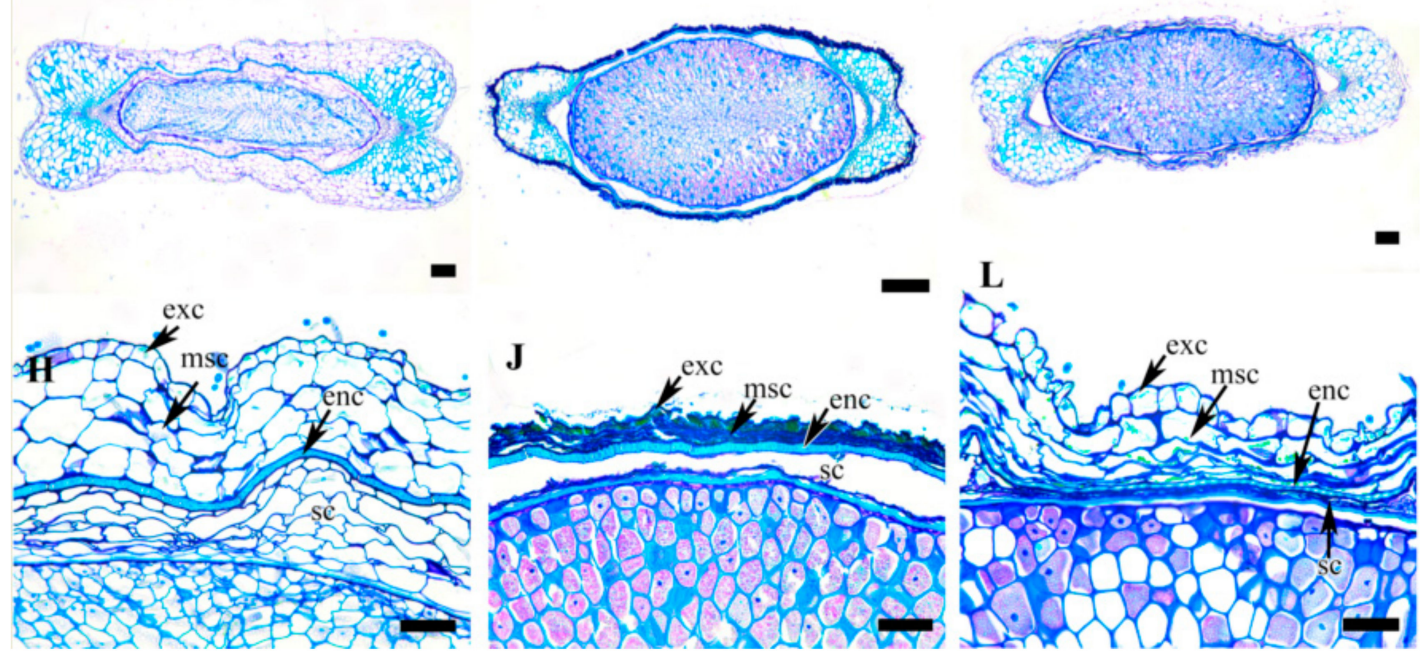

Figure 5. Cross section of achenes of Clematis. (A,B) C. apiifolia. (C,D) C. brevicaudata. (E,F) C. trichotoma. $(\mathbf{G}, \mathbf{H})$ C. taeguensis. $(\mathbf{I}, \mathbf{J})$ C. hexapetala. $(\mathbf{K}, \mathbf{L})$ C. terniflora. Abbreviations: enc, endocarp; exc, exocarp; lw, lateral wing; msc, mesocarp; sc, seed coat; vb, vascular bundle. Scale bars: $200 \mu \mathrm{m}(\mathbf{A}, \mathbf{C}, \mathbf{E}, \mathbf{G}, \mathbf{I}, \mathbf{K})$; $100 \mu \mathrm{m}(\mathbf{B}, \mathbf{D}, \mathbf{F}, \mathbf{H}, \mathbf{J}, \mathbf{L})$. 

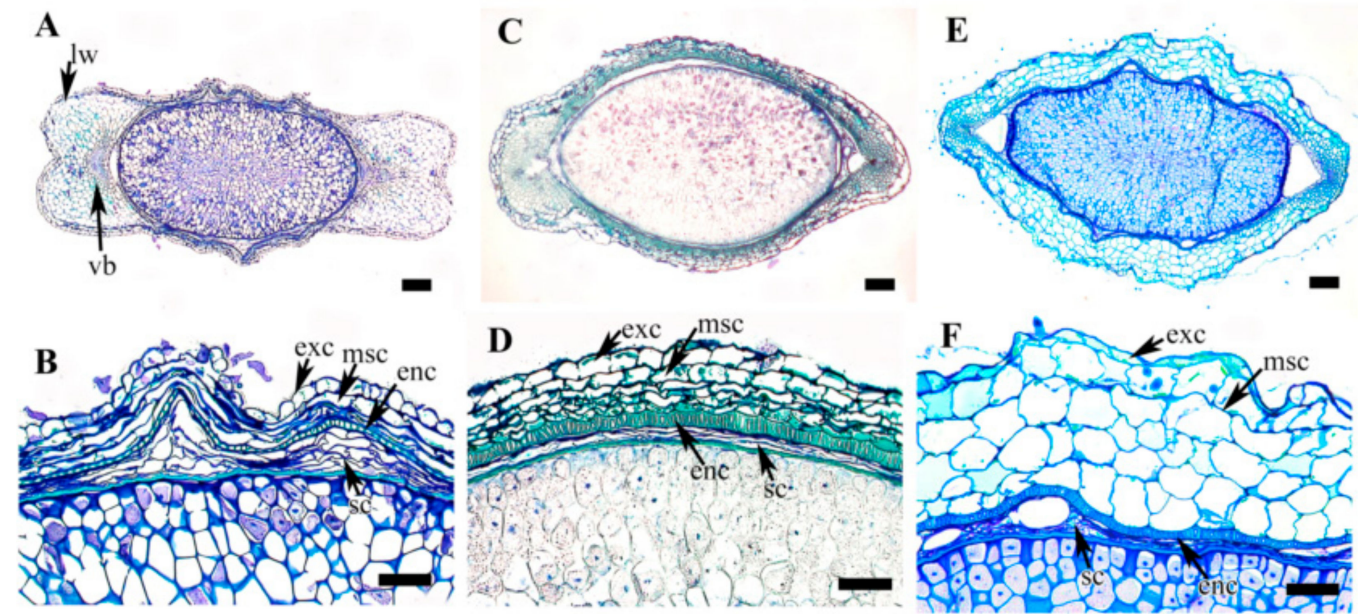

G

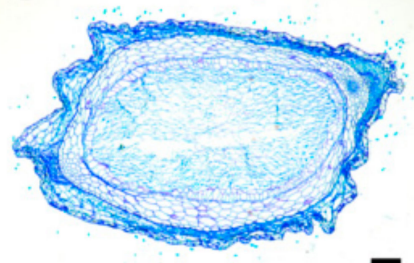

$\mathbf{H}$

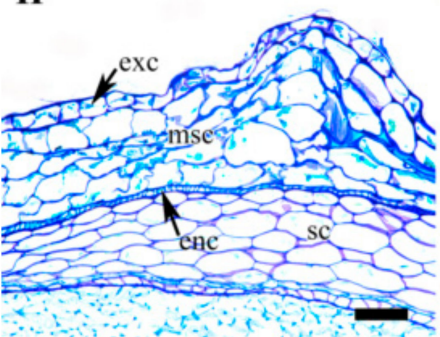

I

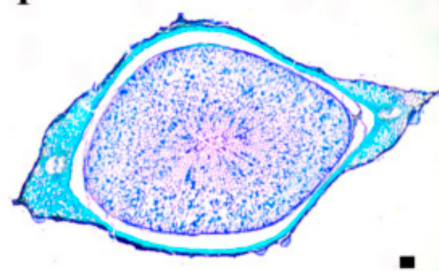

K

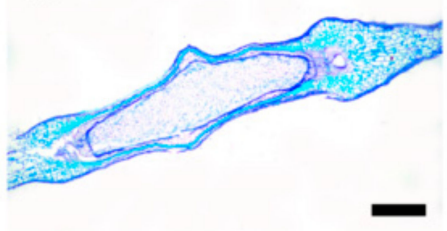

$\mathbf{J}$

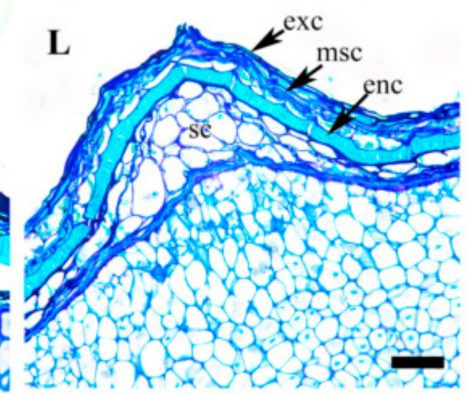

Figure 6. Cross section of achenes of Clematis. (A,B) C. terniflora var. mandshurica. (C,D) C. heraclefolia. (E,F) C. urticifolia. (G, H) Clematis takedana. (I,J) C. patens. (K,L) C. brachyura. Abbreviations: enc, endocarp; exc, exocarp; lw, lateral wing; msc, mesocarp; sc, seed coat; vb, vascular bundle. Scale bars: $1 \mathrm{~mm}(\mathrm{~K}), 200 \mu \mathrm{m}(\mathbf{A}, \mathbf{C}, \mathbf{E}, \mathbf{G}, \mathbf{I}) ; 100 \mu \mathrm{m}(\mathbf{B}, \mathbf{D}, \mathbf{F}, \mathbf{H}, \mathbf{J}, \mathbf{L})$. 
A
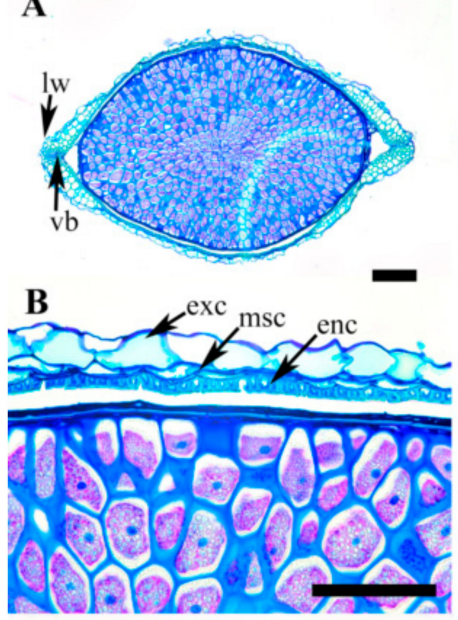

G

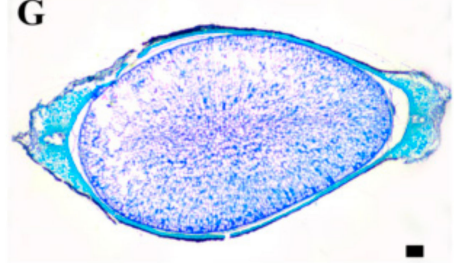

$\mathbf{H}$

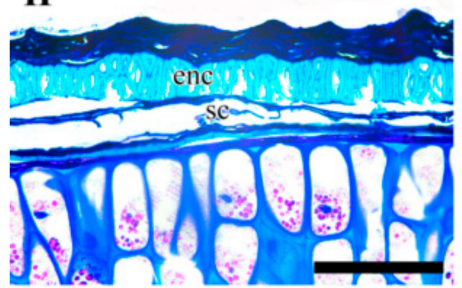

C

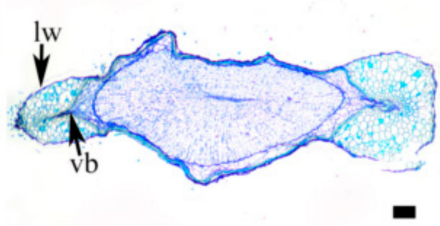

D $\underset{\downarrow}{\operatorname{exc}} \mathrm{msc}_{\downarrow}^{\mathrm{enc}}$
$\mathbf{E}$

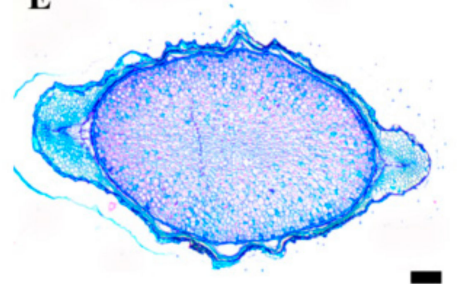

$\mathbf{F}$
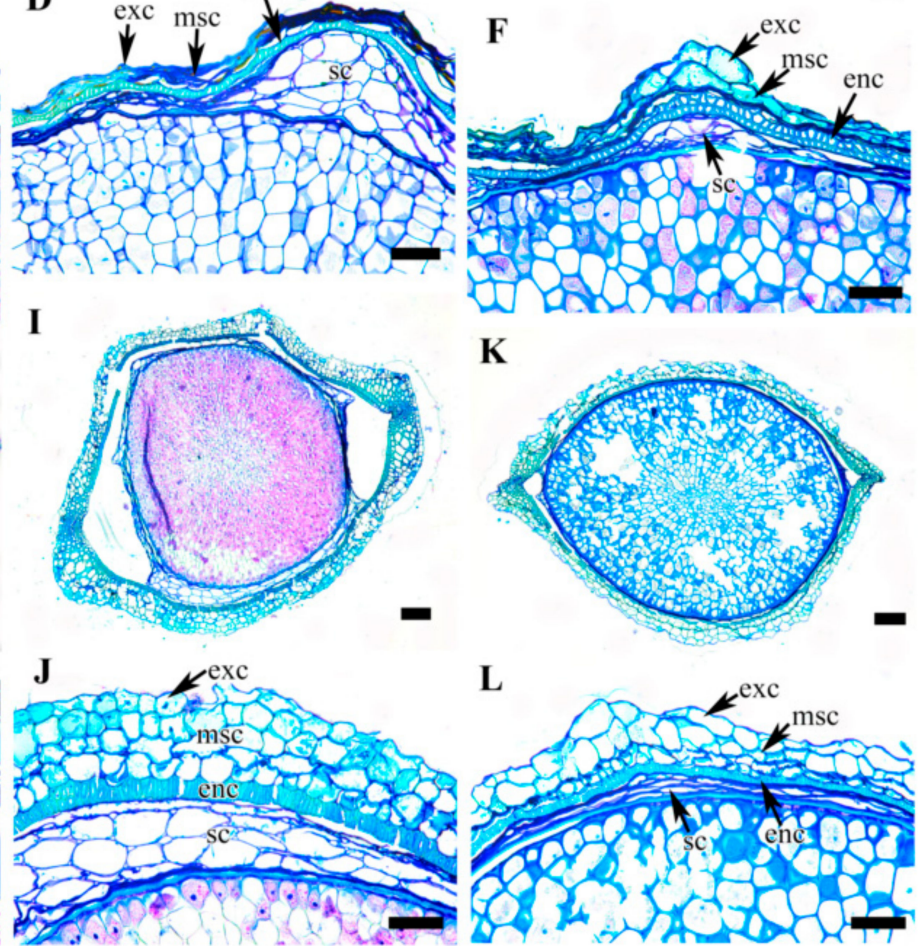

$\mathbf{K}$

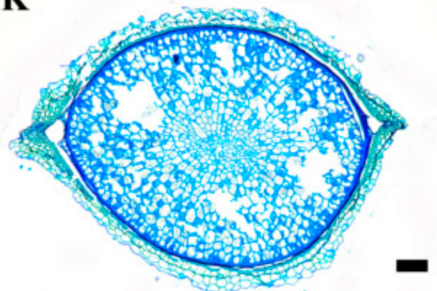

$\mathbf{L}$

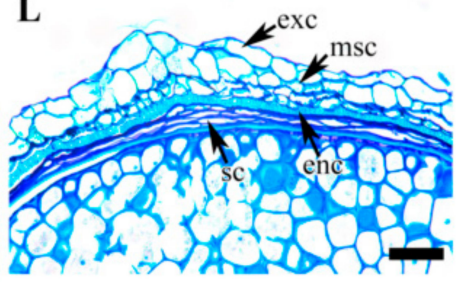

Figure 7. Cross section of achenes of Clematis. (A,B) C. serratifolia. (C,D) C. fusca var. fusca. (E,F) C. fusca var. flabellata. (G,H) C. fusca var. violacea. (I,J) C. koreana. (K,L) C. ochotensis. Abbreviations: enc, endocarp; exc, exocarp; lw, lateral wing; msc, mesocarp; sc, seed coat; vb, vascular bundle. Scale bars: $200 \mu \mathrm{m}(\mathbf{A}, \mathbf{C}, \mathbf{E}, \mathbf{G}, \mathbf{I}, \mathbf{K}) ; 100 \mu \mathrm{m}(\mathbf{B}, \mathbf{D}, \mathbf{F}, \mathbf{H}, \mathbf{J}, \mathbf{L})$.

\subsection{Gross Achene Morphology}

The achenes of Clematis spp. included in this study were black, dark brown, medium brown, brown to black, light yellow and light greenish yellow in color. They were ellipsoidal, narrowly ellipsoidal, ellipsoidal to obovate, obovate, or obovate to fusiform in shape (Figure 1A,D,G,J,M, Figure 2A,D,G,J,M, Figure 3A,D,G,J,M and Figure 4A,D,G,J; Table 2). Clematis brachyura had the largest achene size $(7.99-10.51 \times 6.45-8.02 \mathrm{~mm})$ followed by C. terniflora var. mandshurica $(6.19-7.25 \times 3.02-4.43 \mathrm{~mm})$, whereas C. bravicaudata had the smallest $(2.29-2.93 \times 1.29-1.82 \mathrm{~mm})$. By comparison, C. apiifolia had the narrowest achenes and thus higher length width ratios, whereas $C$. patens had the lowest length/width ratios (close to 1). Based on the measurements from the edges of the achenes' bodies, the lateral wings were narrow (C. apiifolia, C. bravicaudata, C. trochotoma, C. heraclefolia, C. serratifolia, C. calcicola, C. koreana, and C. ochotensis), medium (C. hexapetala, C. urticifolia, C. takedana, C. patens, C. fusca var. flabellata, and C. fusca var. violacea), and wide (C. taeguensis, C. terniflora, C. terniflora var. mandshurica, C. brachyura, and C. fusca var. fusca).

\subsection{Achene Indumentum and Style}

Among the 19 taxa C. trichotoma was the only species with glabrous achene indumenta, whereas the other species were densely or sparsely pilose on the achene bodies and permanent styles (Figure 1A,D,G,J,M, Figure 2A,D,G,J,M, Figure 3A,D,G,J,M and Figure 4A,D,G,J; Table 2). Based 
on the achene body/permanent style length ratios, the included taxa were categorised into strongly elongated achenes (body/style ratio $>5$ ) and elongated achenes (body/style ratio $<5$ ). Clematis brachyura was the only exception with very short (body/style ratio $<1$ ) and glabrous permanent styles and was thus categorised as a non elongated type. Despite the glabrous achene bodies, C. trichotoma had plumose styles.

\subsection{Achene Surface Sculpture}

The primary surface the sculptures of achenes in the studied taxa were striate-rugose: $C$. apiifolia (Figure 1B,C), C. bravicuadata (Figure 1E,F), C. trichotoma (Figure 1K,L), C. hexapetala (Figure 1N,O), C. heraclefolia (Figure 2H,I), C. urticifolia (Figure 2K,L), C. takedana. (Figure 2N,O), and C. patens (Figure 3B,C); striate-colliculate: C. taguensis (Figure 1H,I); striate-reticulate: C. terniflora (Figure 2B,C), C. terniflora var. mandshurica (Figure 2E,F), C. fusca var. fusca (Figure 3K,L), C. fusca var. flabellata (Figure $3 \mathrm{~N}, \mathrm{O}$ ), and C. fusca var. violacea (Figure 4B,C); reticulate C. serratifolia (Figure 3H,I), C. calcicola (Figure 4E,F), C. koreana (Figure 4H,I) and C. ochotensis (Figure 4K,L); and pustulate C. brachyura (Figure 3E,F).

\subsection{Shape of Epidermal Cells}

The surface cells were elongated (C. hexapetala and C. brachyura), elongated-rectangular (C. taeguensis and C. serratifolia), elongated-polygonal (C. koreana and C. ochotensis), rectangular-polygonal (C. terniflora and C. terniflora var. mandshurica), polygonal (C. fusca var. fusca, C. fusca var. flabellata, C. violacea, and C. calcicola), and irregular (C. patens, C. heraclefolia, C. urticifolia, and C. takedana). No specific cell boundaries were observed in C. apiifolia, C. bravicaudata, and $C$. trichotoma. The periclinal wall of the surface cells were dominantly concave with fine folds except in C. taeguensis which has convex periclinal walls with fine folds and C. brachyura with concave walls with tiny pustules. Likewise, the anticlinal wall was dominantly raised, smooth or folded except in C. taeguensis and C. terniflora var. mandshurica which had sunken and smooth anticlinal walls.

\subsection{Achene Anatomy}

The achene shapes in the cross section were mostly fusiform, elliptical, dumbbell or oval-to-elliptical in outline with narrow, medium, or wide lateral wings (Figure 5, Figure 6, Figure 7). Five taxa had elliptical (Figure 5A,C,G and Figure 6C,G), eight taxa had fusiform (Figure 5I, Figure 6E,I,K and Figure 7A,C,E,G), three taxa had dumbbell (Figure 5E,K and Figure 6A), and three taxa had oval-elliptical (Figure 7I,K; C. calcicola not shown) achene outlines in the cross-sections. The species with wide lateral wings had dumbbell-shaped achenes in the cross-section, except for C. brachyura which had large and laterally compressed achenes. The anatomical structure of the achene comprises multiple layers of thick pericarp tailed by a few layered testa of degenerating cell layer or thin-walled parenchymatous cells and a very large endosperm.

The pericarp comprised a single layered exocarp overlying a multilayered mesocarp and single layered endocarp of lignified cells. The exocarp was highly cutinized and the cells were degenerating (C. apiifolia and C. fusca var. violacea; Figures $5 \mathrm{~B}$ and $7 \mathrm{H}$ ), tanniniferous (C. bravicaudata, C. trichotoma, C. hexapetala, C. patens, C. fusca var. fusca, and C. fusca var. flabellata; Figure 5D,H,J, Figures 6J and 7D,F), or parenchymatous with a thick outer wall (remaining taxa including C. calcicola) (Figure 5F,L, Figure $6 \mathrm{~B}, \mathrm{D}, \mathrm{F}, \mathrm{H}, \mathrm{L}$ and Figure $7 \mathrm{~B}, \mathrm{~J}, \mathrm{~L})$. The mesocarp was multilayered, represented by degenerating cells (C. apiifolia, C. hexapetala, C. patens, C. serratifolia, C. fusca var. fusca, C. fusca var. flabellata, and C. fusca var. violacea) or multiple layers of thin-walled parenchymatous cells (the rest of the species). The thickness of the mesocarp ranged from 2-4 layers in C. terniflora, C. brachyura and C. ochotensis to 8-10 layers in C. trichotoma. The multilayered mesocarp overlay a highly lignified single-layered or occasionally double-layered (C. bravicaudata, C. brachyura, C. fusca var. flabellata, C. calcicola, C. koreana, and C. ochotensis) endocarp in all the taxa. The endocarp seems to be the most consistent and vital 
region of the achene wall and probably serve to protect the embryo. The lignified cells may be palisade like or sclerotic (Table 2). As the pericarp takes over the protective role in the seed, the seed coat is poorly represented in mature achenes. The seed coat was represented by a few layers of degenerating cells in most of the species, while some species had several layers of thin-walled parenchymatous cells (Table 2).

The thickest pericarp was observed in C. trichotoma $(238-525 \mu \mathrm{m})$ followed by C. taeguensis $(273-420 \mu \mathrm{m})$, whereas the thinnest was measured in C. serratifolia $(28.82-53.99 \mu \mathrm{m})$, followed by C. hexapetala $(41.43-84.78 \mu \mathrm{m})$ (Table 3). The thickest endocarp was observed in C. patens $(44.8-68.9 \mu \mathrm{m})$, followed by C. fusca var. violacea $(29.32-39.61 \mu \mathrm{m})$ whereas the thinnest was measured in C. apiifolia $(4.72-8.26 \mu \mathrm{m})$ followed by C. terniflora var. mandshurica $(6.9-12.88 \mu \mathrm{m})$.

\subsection{Statistical Analyses}

One-factor ANOVA was performed on nine quantitative achene traits, and the differences between the species were found to be highly significant $(p<0.001)$ (Table 3). The differences in the style length and thicknesses of the pericarp and endocarp are presented in boxplots (Figure 8A-C). The similarities among the species regarding quantitative and qualitative features were revealed using PCA and cluster analysis (Figure 9). The first four components of the PCA explain $91.95 \%$ of the total variation in the analyzed data. The first axis of the first complete set explains $43.52 \%$ of the total variance and shows strong positive loadings for length, width, and cross-sectional diameter perpendicular to the embryo (LE, WE, and CSD2). The second axis explains $23.18 \%$ of the total variance and shows strong positive loadings for the style, endocarp, and cross-sectional diameter parallel to the embryo (ST, EN, and CSD1). The cluster analysis based on the paired group (UPGMA) algorithm using the Euclidean similarity index determined two large clusters uprooted with C. brachyura (Figure 10). The first of these represents 6 taxa whereas the second comprises the remaining 12 taxa and is further divided into at least three subclusters. 
Table 2. Morphological and anatomical features of achene of Clematis.

\begin{tabular}{|c|c|c|c|c|c|c|c|c|c|c|}
\hline Taxon & Shape & Color & $\begin{array}{c}\text { Achene } \\
\text { Indumentum }\end{array}$ & $\begin{array}{l}\text { Lateral } \\
\text { Wings }\end{array}$ & $\begin{array}{c}\text { Style } \\
\text { Elongation }\end{array}$ & Style & $\begin{array}{c}\text { Surface } \\
\text { Sculpture }\end{array}$ & $\begin{array}{l}\text { Surface Cells } \\
\text { Outline }\end{array}$ & Periclinal Wall & $\begin{array}{c}\text { Anticlina } \\
\text { Wall }\end{array}$ \\
\hline C. apiifolia & Narrow-elliptical & Brown & $\begin{array}{l}\text { Completely hairy, } \\
\text { hairs short on } \\
\text { the achene body } \\
\text { and long on the style }\end{array}$ & Narrow & Elongated & Plumose & Striate-rugose & $\begin{array}{c}\text { Not } \\
\text { differentiated }\end{array}$ & $\begin{array}{l}\text { Concave with } \\
\text { fine folds }\end{array}$ & $\begin{array}{l}\text { Raised, } \\
\text { folded }\end{array}$ \\
\hline C. brevicaudata & Elliptic & Brown & $\begin{array}{l}\text { Completely hairy, } \\
\text { hairs short on } \\
\text { the achene body } \\
\text { and long on the style }\end{array}$ & Narrow & $\begin{array}{l}\text { Strongly } \\
\text { elongated }\end{array}$ & Plumose & Striate-rugose & $\begin{array}{c}\text { Not } \\
\text { differentiated }\end{array}$ & $\begin{array}{l}\text { Concave with } \\
\text { fine folds }\end{array}$ & $\begin{array}{l}\text { Raised, } \\
\text { folded }\end{array}$ \\
\hline C. trichotoma & $\begin{array}{l}\text { Obovate to } \\
\text { fusiform }\end{array}$ & Black & Glabrous & Narrow & $\begin{array}{c}\text { Strongly } \\
\text { elongated }\end{array}$ & Plumose & Striate-rugose & $\begin{array}{c}\text { Not } \\
\text { differentiated }\end{array}$ & $\begin{array}{l}\text { Concave with } \\
\text { fine folds }\end{array}$ & $\begin{array}{l}\text { Slightly } \\
\text { raised }\end{array}$ \\
\hline C. taeguensis & $\begin{array}{l}\text { Elliptical to } \\
\text { obovate }\end{array}$ & Light yellow & $\begin{array}{l}\text { Sparsely hairy, fine } \\
\text { hair on the body } \\
\text { and long on the style }\end{array}$ & Wide & $\begin{array}{l}\text { Strongly } \\
\text { elongated }\end{array}$ & Plumose & Striate-colliculate & $\begin{array}{l}\text { Elongated, } \\
\text { rectangular }\end{array}$ & $\begin{array}{l}\text { Convex with } \\
\text { fine folds }\end{array}$ & $\begin{array}{l}\text { Sunken, } \\
\text { smooth }\end{array}$ \\
\hline C. hexapetala & Obovate & $\begin{array}{l}\text { Dark brown to } \\
\text { black }\end{array}$ & Completely hairy & Medium & Elongated & Plumose & Striate-rugose & Elongated & $\begin{array}{l}\text { Concave with } \\
\text { fine folds }\end{array}$ & $\begin{array}{l}\text { Raised, } \\
\text { folded }\end{array}$ \\
\hline C. terniflora & Elliptic to Obovate & Brown & $\begin{array}{l}\text { Sparsely hairy, fine } \\
\text { hair on the body } \\
\text { and long on the style }\end{array}$ & Wide & Elongated & Plumose & Striate-reticulate & $\begin{array}{l}\text { Rectangular, } \\
\text { polygonal }\end{array}$ & $\begin{array}{l}\text { Concave with } \\
\text { fine folds }\end{array}$ & $\begin{array}{l}\text { Raised, } \\
\text { smooth }\end{array}$ \\
\hline $\begin{array}{l}\text { C. terniflora var. } \\
\text { mandshurica }\end{array}$ & Elliptic & Light yellow & $\begin{array}{l}\text { Sparsely hairy, fine } \\
\text { hair on the body } \\
\text { and long on the style }\end{array}$ & Wide & Elongated & Plumose & Striate-reticulate & $\begin{array}{l}\text { Rectangular, } \\
\text { polygonal }\end{array}$ & $\begin{array}{l}\text { Concave with } \\
\text { fine folds }\end{array}$ & $\begin{array}{l}\text { Sunken, } \\
\text { smooth }\end{array}$ \\
\hline C. heracleifolia & Obovate & Dark brown & Completely hairy & Narrow & $\begin{array}{c}\text { Strongly } \\
\text { elongated }\end{array}$ & Plumose & Striate-rugose & Irregular & $\begin{array}{l}\text { Concave with } \\
\text { fine folds }\end{array}$ & $\begin{array}{l}\text { Raised, } \\
\text { folded }\end{array}$ \\
\hline C. urticifolia & Elliptic to Obovate & $\begin{array}{l}\text { Light greenish } \\
\text { yellow }\end{array}$ & Completely hairy & Medium & $\begin{array}{c}\text { Strongly } \\
\text { elongated }\end{array}$ & Plumose & Striate-rugose & Irregular & $\begin{array}{l}\text { Concave with } \\
\text { fine folds }\end{array}$ & $\begin{array}{l}\text { Raised, } \\
\text { folded }\end{array}$ \\
\hline C. takedana & Obovate & $\begin{array}{l}\text { Dark brown to } \\
\text { black }\end{array}$ & Completely hairy & Medium & $\begin{array}{c}\text { Strongly } \\
\text { elongated }\end{array}$ & Plumose & Striate-rugose & Irregular & $\begin{array}{l}\text { Concave with } \\
\text { fine folds }\end{array}$ & $\begin{array}{l}\text { Raised, } \\
\text { folded }\end{array}$ \\
\hline C. patens & Obovate & $\begin{array}{l}\text { Dark brown to } \\
\text { black }\end{array}$ & $\begin{array}{l}\text { Completely hairy, } \\
\text { hairs short on } \\
\text { the achene body } \\
\text { and long on the style }\end{array}$ & Medium & $\begin{array}{l}\text { Strongly } \\
\text { elongated }\end{array}$ & Plumose & Striate-rugose & Irregular & $\begin{array}{l}\text { Concave with } \\
\text { fine folds }\end{array}$ & $\begin{array}{l}\text { Raised, } \\
\text { folded }\end{array}$ \\
\hline C. brachyura & Obovate & Brown, black & Sparsely hairy & Wide & Not elongated & Glabrous & $\begin{array}{c}\text { Rugose, } \\
\text { Pustulate }\end{array}$ & Elongated & $\begin{array}{l}\text { Concave } \\
\text { pustulate }\end{array}$ & $\begin{array}{c}\text { Raised, } \\
\text { pustulate }\end{array}$ \\
\hline C. serratifolia & Obovate & Medium brown & $\begin{array}{l}\text { Sparsely hairy, fine } \\
\text { hair on the body } \\
\text { and long on the style }\end{array}$ & Narrow & $\begin{array}{l}\text { Strongly } \\
\text { elongated }\end{array}$ & Plumose & Reticulate & $\begin{array}{l}\text { Elongated, } \\
\text { rectangular }\end{array}$ & $\begin{array}{l}\text { Concave with } \\
\text { fine folds }\end{array}$ & $\begin{array}{l}\text { raised, } \\
\text { smooth }\end{array}$ \\
\hline
\end{tabular}


Table 2. Cont

\begin{tabular}{|c|c|c|c|c|c|c|c|c|c|c|}
\hline Taxon & Shape & Color & $\begin{array}{c}\text { Achene } \\
\text { Indumentum }\end{array}$ & $\begin{array}{l}\text { Lateral } \\
\text { Wings }\end{array}$ & $\begin{array}{c}\text { Style } \\
\text { Elongation }\end{array}$ & Style & $\begin{array}{l}\text { Surface } \\
\text { Sculpture }\end{array}$ & $\begin{array}{c}\text { Surface Cells } \\
\text { Outline }\end{array}$ & Periclinal Wall & $\begin{array}{c}\text { Anticlinal } \\
\text { Wall }\end{array}$ \\
\hline C. fusca var. fusca & Obovate & $\begin{array}{l}\text { Dark brown } \\
\text { to black }\end{array}$ & Completely hairy & Wide & $\begin{array}{l}\text { Strongly } \\
\text { elongated }\end{array}$ & Plumose & Striate-reticulate & Polygonal & $\begin{array}{l}\text { Concave with } \\
\text { fine folds }\end{array}$ & $\begin{array}{l}\text { Raised } \\
\text { smooth or } \\
\text { fine folds }\end{array}$ \\
\hline C. fusca var. flabellata & Elliptic to Obovate & Brown & Completely hairy & Medium & $\begin{array}{l}\text { Strongly } \\
\text { elongated }\end{array}$ & Plumose & Striate-reticulate & Polygonal & $\begin{array}{l}\text { Concave with } \\
\text { fine folds }\end{array}$ & $\begin{array}{l}\text { Slightly } \\
\text { raised, } \\
\text { smooth }\end{array}$ \\
\hline C. fusca var. violacea & Obovate & Black & Completely hairy & Medium & $\begin{array}{l}\text { Strongly } \\
\text { elongated }\end{array}$ & Plumose & Striate-reticulate & Polygonal & $\begin{array}{l}\text { Concave with } \\
\text { fine folds }\end{array}$ & $\begin{array}{l}\text { Raised } \\
\text { smooth or } \\
\text { fine folds }\end{array}$ \\
\hline C. calcicola & Narrow-elliptical & Dark brown & Completely hairy & Narrow & $\begin{array}{l}\text { Strongly } \\
\text { elongated }\end{array}$ & Plumose & Reticulate & Polygonal & $\begin{array}{l}\text { Concave with } \\
\text { fine folds }\end{array}$ & $\begin{array}{l}\text { Raised } \\
\text { smooth or } \\
\text { fine folds }\end{array}$ \\
\hline C. koreana & Obovate & Medium brown & Completely hairy & Narrow & $\begin{array}{l}\text { Strongly } \\
\text { elongated }\end{array}$ & Plumose & Reticulate & $\begin{array}{l}\text { Elongated, } \\
\text { polygonal }\end{array}$ & $\begin{array}{l}\text { Concave with } \\
\text { fine folds }\end{array}$ & $\begin{array}{l}\text { Raised } \\
\text { smooth or } \\
\text { fine folds }\end{array}$ \\
\hline C. ochotensis & Obovate & Brown & $\begin{array}{l}\text { Sparsely hairy, fine } \\
\text { hairs on the body } \\
\text { and long on the style }\end{array}$ & Narrow & $\begin{array}{l}\text { Strongly } \\
\text { elongated }\end{array}$ & Plumose & Reticulate & $\begin{array}{l}\text { Elongated, } \\
\text { polygonal }\end{array}$ & $\begin{array}{l}\text { Concave with } \\
\text { fine folds }\end{array}$ & $\begin{array}{l}\text { Raised } \\
\text { smooth or } \\
\text { fine folds }\end{array}$ \\
\hline \multicolumn{2}{|c|}{ Taxon } & Outline in CS & \multicolumn{2}{|l|}{ Exocarp } & \multicolumn{2}{|c|}{ Mesocarp } & \multicolumn{2}{|c|}{ Endocarp } & \multicolumn{2}{|c|}{ Seed Coat } \\
\hline \multicolumn{2}{|c|}{ C. apiifolia } & Elliptic & \multicolumn{2}{|c|}{ Degenerating cells } & \multicolumn{2}{|c|}{ Few layers of degenerating cells } & \multicolumn{2}{|c|}{ Thin, single layer of lignified cells } & \multicolumn{2}{|c|}{ Degenerated } \\
\hline \multicolumn{2}{|c|}{ C. brevicaudata } & Elliptic & \multicolumn{2}{|c|}{ Cutinized single tanniniferous layer } & \multicolumn{2}{|c|}{$\begin{array}{c}\text { 3-4 layers of parenchyma layer } \\
\text { with wavy wall }\end{array}$} & \multicolumn{2}{|c|}{$\begin{array}{l}\text { Thick, single layer (rarely double } \\
\text { layer) sclerid cells }\end{array}$} & \multicolumn{2}{|c|}{ Few layers of parenchyma cells } \\
\hline \multicolumn{2}{|c|}{ C. trichotoma } & Elliptic & \multicolumn{2}{|c|}{ Cutinized single tanniniferous layer } & \multicolumn{2}{|c|}{$\begin{array}{l}\text { 8-10 layers of thin walled } \\
\text { parenchyma cells with } \\
\text { wavy wall }\end{array}$} & \multicolumn{2}{|c|}{ Thin, single layer of lignified cells } & \multicolumn{2}{|c|}{ 1-2 layers of degenerating cells } \\
\hline \multicolumn{2}{|c|}{ C. taeguensis } & Dumbbell & \multicolumn{2}{|c|}{$\begin{array}{l}\text { Cutinized single layer parenchyma } \\
\text { cells with thick outer wall }\end{array}$} & \multicolumn{2}{|c|}{$\begin{array}{l}\text { 4-6 layers of thin walled } \\
\text { parenchyma cells with } \\
\text { wavy wall }\end{array}$} & \multicolumn{2}{|c|}{ Thick, single layer of sclerid cells } & \multicolumn{2}{|c|}{ 5-7 layers of parenchyma cells } \\
\hline \multicolumn{2}{|c|}{ C. hexapetala } & Fusiform & \multicolumn{2}{|c|}{ Cutinized single tanniniferous layer } & \multicolumn{2}{|c|}{ Few layers of degenerating cells } & \multicolumn{2}{|c|}{ Thick, single layer of sclerid cells } & \multicolumn{2}{|c|}{ Few layers of degenerating cells } \\
\hline \multicolumn{2}{|c|}{ C. terniflora } & Dumbbell & \multicolumn{2}{|c|}{$\begin{array}{l}\text { Cutinized single layer parenchyma } \\
\text { cells with thick outer wall }\end{array}$} & \multicolumn{2}{|c|}{$\begin{array}{l}\text { 2-4 layers of thin walled } \\
\text { parenchyma cells with } \\
\text { wavy wall }\end{array}$} & \multicolumn{2}{|c|}{ Single layer of sclerid cells } & \multicolumn{2}{|c|}{ Few layers of degenerating cells } \\
\hline \multicolumn{2}{|c|}{ C. terniflora var. mandshurica } & Dumbbell & $\begin{array}{l}\text { Cutinized single laye } \\
\text { cells with thick o }\end{array}$ & $\begin{array}{l}\text { arenchyma } \\
\text { er wall }\end{array}$ & $\begin{array}{r}\text { 4-6 layers } \\
\text { parenchys } \\
\text { way }\end{array}$ & $\begin{array}{l}\text { in walled } \\
\text { ells with } \\
\text { all }\end{array}$ & Thick, single lay & of sclerid cells & Few layers of pa & nchyma cells \\
\hline C. hera & ifolia & Fusiform & $\begin{array}{r}\text { Cutinized single laye } \\
\text { cells with thick o }\end{array}$ & $\begin{array}{l}\text { arenchyma } \\
\text { er wall }\end{array}$ & $\begin{array}{r}\text { 4-6 layers } \\
\text { parenchys } \\
\text { was }\end{array}$ & $\begin{array}{l}\text { in walled } \\
\text { ells with } \\
\text { all }\end{array}$ & $\begin{array}{r}\text { Thick, single } 1 \mathrm{c} \\
\text { palisa }\end{array}$ & $\begin{array}{l}\text { er of lignified } \\
\text { cells }\end{array}$ & Few layers of de & nerating cells \\
\hline
\end{tabular}


Table 2. Cont.

\begin{tabular}{|c|c|c|c|c|c|}
\hline Shape & Color & $\begin{array}{c}\text { Achene } \\
\text { Indumentum }\end{array}$ & $\begin{array}{c}\text { Style } \\
\text { Elongation }\end{array}$ & $\begin{array}{l}\text { Surface Cells } \\
\text { Outline }\end{array}$ & Periclinal Wall \\
\hline C. urticifolia & Elliptic & $\begin{array}{l}\text { Cutinized single layer parenchyma } \\
\text { cells with thick outer wall }\end{array}$ & $\begin{array}{l}\text { 4-6 layers of thin walled } \\
\text { parenchyma cells with } \\
\text { wavy wall }\end{array}$ & Single layer of sclerid cells & Few layers of degenerating cells \\
\hline C. takedana & Elliptic & $\begin{array}{l}\text { Cutinized single layer parenchyma } \\
\text { cells with thick outer wall }\end{array}$ & $\begin{array}{l}\text { 6-8 layers of thin walled } \\
\text { parenchyma cells with } \\
\text { wavy wall }\end{array}$ & Thin, single layer of lignified cells & 5-7 layers of parenchyma cells \\
\hline C. patens & Fusiform & Cutinized single tanniniferous layer & Few layers of degenerating cells & $\begin{array}{l}\text { Thick, single layer of lignified } \\
\text { palisade cells }\end{array}$ & Few layers of parenchyma cells \\
\hline C. brachyura & $\begin{array}{l}\text { Narrowly } \\
\text { fusiform }\end{array}$ & $\begin{array}{l}\text { Cutinized single layer parenchyma } \\
\text { cells with thick outer wall }\end{array}$ & $\begin{array}{l}\text { 2-4 layers of thin walled } \\
\text { parenchyma cells with } \\
\text { wavy wall }\end{array}$ & $\begin{array}{l}\text { Thick, single layer (rarely double } \\
\text { layer) sclerid cells }\end{array}$ & $3-5$ layers of parenchyma cells \\
\hline C. serratifolia & Fusiform & $\begin{array}{l}\text { Cutinized single layer parenchyma } \\
\text { cells with thick outer wall }\end{array}$ & Few layers of degenerating cells & $\begin{array}{l}\text { Thick, single layer of lignified } \\
\text { palisade cells }\end{array}$ & Few layers of degenerating cells \\
\hline C. fusca var. fusca & Fusiform & Cutinized single taniniferous layer & Few layers of degenerating cells & Single layer of sclerid cells & 5-7 layers of parenchyma cells \\
\hline C. fusca var. flabellata & Fusiform & Cutinized single taniniferous layer & Few layers of degenerating cells & $\begin{array}{l}\text { Thick, single layer (rarely double } \\
\text { layer) sclerid cells }\end{array}$ & Few layers of degenerating cells \\
\hline C. fusca var. violacea & Fusiform & Degenerated & Few layers of degenerating cells & $\begin{array}{c}\text { Thick, single layer of lignified } \\
\text { palisade cells }\end{array}$ & Few layers of degenerating cells \\
\hline C. calcicola & Oval, elliptical & $\begin{array}{l}\text { Cutinized single layer parenchyma } \\
\text { cells with thick outer wall }\end{array}$ & $\begin{array}{c}\text { 6-8 layers of thin walled } \\
\text { parenchyma cells with } \\
\text { wavy wall }\end{array}$ & $\begin{array}{l}\text { Thick, single layer (rarely double } \\
\text { layer) sclerid cells }\end{array}$ & Few layers of degenerating cells \\
\hline C. koreana & Oval, elliptical & $\begin{array}{l}\text { Cutinized single layer parenchyma } \\
\text { cells with thick outer wall }\end{array}$ & $\begin{array}{c}\text { 6-8 layers of thin walled } \\
\text { parenchyma cells with } \\
\text { wavy wall }\end{array}$ & $\begin{array}{l}\text { Thick, single layer (rarely double } \\
\text { layer) sclerid cells }\end{array}$ & 3-5 layers of parenchyma cells \\
\hline C. ochotensis & Oval, elliptical & $\begin{array}{l}\text { Cutinized single layer parenchyma } \\
\text { cells with thick outer wall }\end{array}$ & $\begin{array}{l}\text { 2-3 layers of thin walled } \\
\text { parenchyma cells with } \\
\text { wavy wall }\end{array}$ & $\begin{array}{l}\text { Thin, single layer (rarely double } \\
\text { layer) sclerid cells }\end{array}$ & Few layers of degenerating cells \\
\hline
\end{tabular}


Table 3. One-factor ANOVA for the achene characters and their measurements in Clematis taxa (mean and standard deviation). L/W = length and width ratio, $\mathrm{P} / \mathrm{E}=$ pericarp and endocarp ratio, $\mathrm{S} / \mathrm{B}=$ style and achene body ratio, $\mathrm{CSD} 1=$ diameter parallel to cotyledon, CSD2 = diameter perpendicular to cotyledon, $\mathrm{D} 1 / \mathrm{D} 2=\mathrm{CSD} 1$ and CSD2 ratio.

\begin{tabular}{|c|c|c|c|c|c|c|c|c|c|c|c|}
\hline Taxon & $\begin{array}{c}\text { Length } \\
(\mathrm{mm})\end{array}$ & $\begin{array}{l}\text { Width } \\
\text { (mm) }\end{array}$ & $\mathrm{L} / \mathrm{W}$ & Pericarp $(\mu \mathrm{m})$ & $\begin{array}{c}\text { Endocarp } \\
(\mu \mathrm{m})\end{array}$ & $\mathrm{P} / \mathrm{E}$ & Style (mm) & S/B & $\begin{array}{l}\text { CSD1 } \\
(\mathrm{mm})\end{array}$ & $\begin{array}{l}\text { CSD2 } \\
(\mathrm{mm})\end{array}$ & CSD1/CSD2 \\
\hline C. apiifolia & $3.95 \pm 0.4$ & $1.32 \pm 0.2$ & $3.01 \pm 0.21$ & $63.51 \pm 15.58$ & $6.32 \pm 1.06$ & $10 \pm 1.36$ & $9.55 \pm 1.29$ & $2.44 \pm 0.38$ & $1.66 \pm 0.04$ & $1.08 \pm 0.07$ & $1.54 \pm 0.08$ \\
\hline C. brevicaudata & $2.53 \pm 0.19$ & $1.62 \pm 0.18$ & $1.59 \pm 0.21$ & $104.89 \pm 26.35$ & $12.03 \pm 3$ & $8.99 \pm 2.56$ & $25.74 \pm 3.24$ & $10.17 \pm 1.17$ & $2.07 \pm 0.05$ & $1.15 \pm 0.09$ & $1.8 \pm 0.15$ \\
\hline C. trichotoma & $4 \pm 0.27$ & $2.67 \pm 0.24$ & $1.5 \pm 0.05$ & $343.62 \pm 68.40$ & $9.97 \pm 1.52$ & $35.94 \pm 6.86$ & $27.74 \pm 3.04$ & $6.95 \pm 0.83$ & $3.06 \pm 0.28$ & $2.17 \pm 0.39$ & $1.43 \pm 0.16$ \\
\hline C. taeguensis & $4.3 \pm 0.47$ & $3.3 \pm 0.48$ & $1.34 \pm 0.21$ & $327.13 \pm 46.45$ & $12.06 \pm 1.64$ & $27.19 \pm 2.17$ & $35.35 \pm 3.48$ & $8.25 \pm 1.2$ & $3.28 \pm 0.08$ & $1.15 \pm 0.1$ & $2.87 \pm 0.24$ \\
\hline C. hexapetala & $4.73 \pm 0.4$ & $2.88 \pm 0.2$ & $1.64 \pm 0.04$ & $56.52 \pm 11.77$ & $13.47 \pm 1.93$ & $4.17 \pm 0.35$ & $15.01 \pm 2.33$ & $3.21 \pm 0.63$ & $2.93 \pm 0.21$ & $1.38 \pm 0.19$ & $2.13 \pm 0.14$ \\
\hline C. terniflora & $5.44 \pm 0.43$ & $3.12 \pm 0.3$ & $1.75 \pm 0.06$ & $94.85 \pm 29.49$ & $11.84 \pm 2.05$ & $7.83 \pm 1.24$ & $25.97 \pm 4.08$ & $4.76 \pm 0.74$ & $3.44 \pm 0.3$ & $1.33 \pm 0.14$ & $2.6 \pm 0.14$ \\
\hline $\begin{array}{l}\text { C. terniflora var. } \\
\text { mandshurica }\end{array}$ & $6.75 \pm 0.39$ & $3.5 \pm 0.4$ & $1.94 \pm 0.13$ & $84.89 \pm 16.41$ & $9.84 \pm 1.43$ & $8.72 \pm 1.65$ & $31.66 \pm 3.24$ & $4.71 \pm 0.55$ & $3.73 \pm 0.21$ & $1.47 \pm 0.12$ & $2.55 \pm 0.21$ \\
\hline C. heracleifolia & $3.21 \pm 0.36$ & $2.01 \pm 0.25$ & $1.6 \pm 0.0 .08$ & $136.06 \pm 25.36$ & $25.61 \pm 4.41$ & $5.3 \pm 0.17$ & $17.07 \pm 2.55$ & $5.4 \pm 1.21$ & $3.01 \pm 0.48$ & $1.42 \pm 0.12$ & $2.21 \pm 0.18$ \\
\hline C. urticifolia & $3.83 \pm 0.25$ & $2.9 \pm 0.27$ & $1.33 \pm 0.09$ & $285.8 \pm 41.04$ & $16.35 \pm 3.12$ & $17.24 \pm 4.21$ & $26.55 \pm 3.8$ & $6.97 \pm 1.25$ & $2.89 \pm 0.37$ & $1.49 \pm 0.09$ & $1.94 \pm 0.33$ \\
\hline C. takedana & $2.88 \pm 0.38$ & $1.86 \pm 0.22$ & $1.56 \pm 0.21$ & $232.31 \pm 52.36$ & $9.94 \pm 2.27$ & $23.92 \pm 5.1$ & $26.23 \pm 3.7$ & $9.3 \pm 1.64$ & $2.08 \pm 0.08$ & $1.27 \pm 0.16$ & $1.66 \pm 0.26$ \\
\hline C. patens & $4.04 \pm 0.3$ & $3.68 \pm 0.51$ & $1.12 \pm 0.16$ & $183.29 \pm 18.69$ & $57.69 \pm 7.41$ & $3.33 \pm 0.83$ & $30.21 \pm 5.17$ & $7.51 \pm 1.41$ & $4.95 \pm 0.2$ & $2.45 \pm 0.13$ & $2.03 \pm 0.18$ \\
\hline C. brachyura & $9.12 \pm 0.88$ & $7.3 \pm 0.46$ & $1.25 \pm 0.10$ & $142.19 \pm 28.08$ & $22.44 \pm 3.39$ & $6.37 \pm 1.04$ & $2.99 \pm 0.55$ & $0.33 \pm 0.07$ & $7.1 \pm 0.14$ & $1.08 \pm 0.11$ & $6.65 \pm 0.6$ \\
\hline C. serratifolia & $2.86 \pm 0.17$ & $1.42 \pm 0.13$ & $2.02 \pm 0.11$ & $41.44 \pm 6.93$ & $12.83 \pm 2.09$ & $3.23 \pm 0.14$ & $27.16 \pm 4.52$ & $9.51 \pm 1.62$ & $1.61 \pm 0.04$ & $1.04 \pm 0.1$ & $1.6 \pm 0.12$ \\
\hline C. fusca var. fusca & $4.64 \pm 0.41$ & $2.99 \pm 0.28$ & $1.52 \pm 0.07$ & $89.63 \pm 25.9$ & $13.29 \pm 1.93$ & $6.9 \pm 2.26$ & $28.61 \pm 6.65$ & $6.25 \pm 1.71$ & $3.58 \pm 0.17$ & $1.21 \pm 0.08$ & $2.96 \pm 0.2$ \\
\hline C. fusca var. flabellata & $3.77 \pm 0.3$ & $2.49 \pm 0.23$ & $1.14 \pm 0.06$ & $77.92 \pm 25.31$ & $12.51 \pm 2.71$ & $6.3 \pm 0.95$ & $35.71 \pm 4.9$ & $9.55 \pm 1.72$ & $2.86 \pm 0.11$ & $1.65 \pm 0.08$ & $1.73 \pm 0.02$ \\
\hline C. fusca var. violacea & $6.1 \pm 0.7$ & $5.34 \pm 0.51$ & $1.18 \pm 0.38$ & $70.3 \pm 12.45$ & $34.1 \pm 3.54$ & $2.05 \pm 0.16$ & $44.74 \pm 5.81$ & $7.37 \pm 0.9$ & $5.16 \pm 0.15$ & $1.92 \pm 0.32$ & $2.73 \pm 0.34$ \\
\hline C. calcicola & $4.44 \pm 0.48$ & $2.07 \pm 0.25$ & $2.18 \pm 0.38$ & $222.95 \pm 25.82$ & $24.27 \pm 4.22$ & $9.35 \pm 2.25$ & $28.48 \pm 4.29$ & $6.48 \pm 1.23$ & $2.86 \pm 0.25$ & $1.85 \pm 0.3$ & $1.59 \pm 0.33$ \\
\hline C. koreana & $4.77 \pm 0.35$ & $2.55 \pm 0.36$ & $1.88 \pm 0.12$ & $111.82 \pm 26.78$ & $27.66 \pm 3.51$ & $4.11 \pm 0.46$ & $31.85 \pm 4.95$ & $6.7 \pm 1.14$ & $2.36 \pm 0.07$ & $1.66 \pm 0.08$ & $1.42 \pm 0.04$ \\
\hline C. ochotensis & $3.76 \pm 0.25$ & $1.64 \pm 0.26$ & $2.35 \pm 0.39$ & $111.83 \pm 16.44$ & $12.57 \pm 1.5$ & $8.96 \pm 1.42$ & $28.56 \pm 2.45$ & $7.64 \pm 0.89$ & $1.81 \pm 0.19$ & $1.29 \pm 0.15$ & $1.42 \pm 0.3$ \\
\hline ANOVA & $\begin{array}{c}\mathrm{F}=206.22 \\
p<0.001\end{array}$ & $\begin{array}{l}\mathrm{F}=298.9 \\
p<0.001\end{array}$ & $\begin{array}{c}\mathrm{F}=101.98 \\
p<0.001\end{array}$ & $\begin{array}{c}\mathrm{F}=121.01 \\
p<0.001\end{array}$ & $\begin{array}{c}\mathrm{F}=182.24 \\
p<0.001\end{array}$ & $\begin{array}{c}\mathrm{F}=190.03 \\
p<0.001\end{array}$ & $\begin{array}{c}\mathrm{F}=83.7 \\
p<0.001\end{array}$ & $\begin{array}{l}\mathrm{F}=72.68 \\
p<0.001\end{array}$ & $\begin{array}{c}\mathrm{F}=210.17, \\
p<0.001\end{array}$ & $\begin{array}{l}\mathrm{F}=26.89 \\
p<0.001\end{array}$ & $\begin{array}{c}\mathrm{F}=114.58, \\
p<0.001\end{array}$ \\
\hline
\end{tabular}




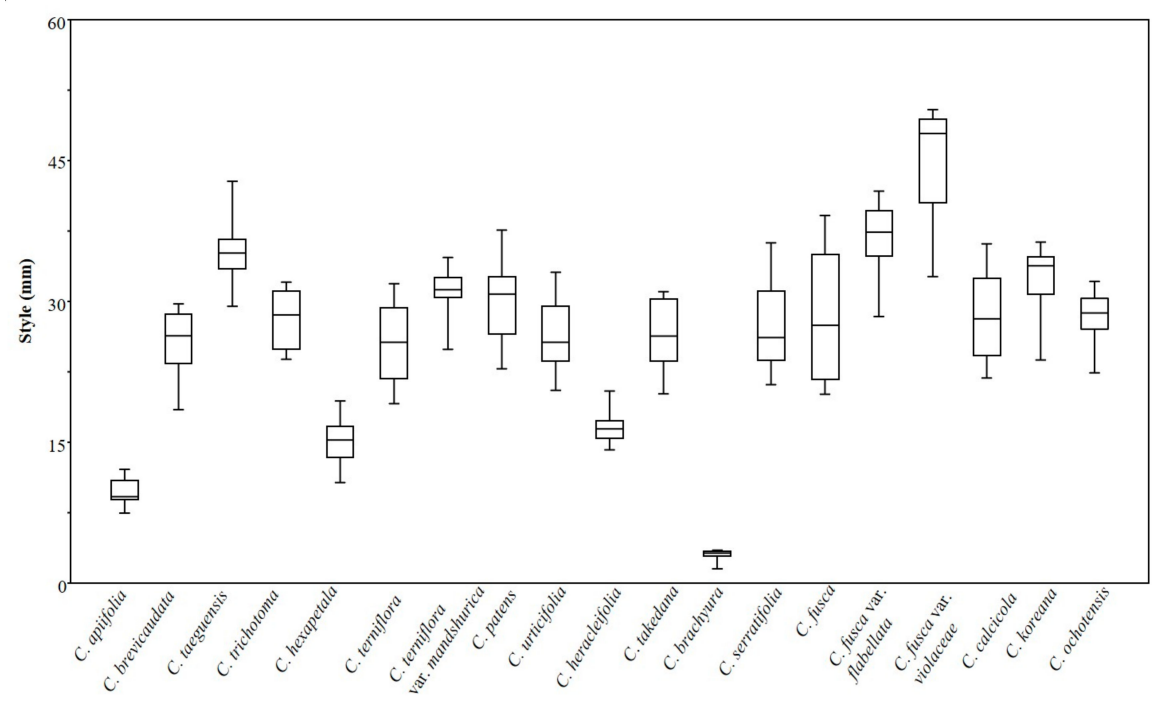

(A)

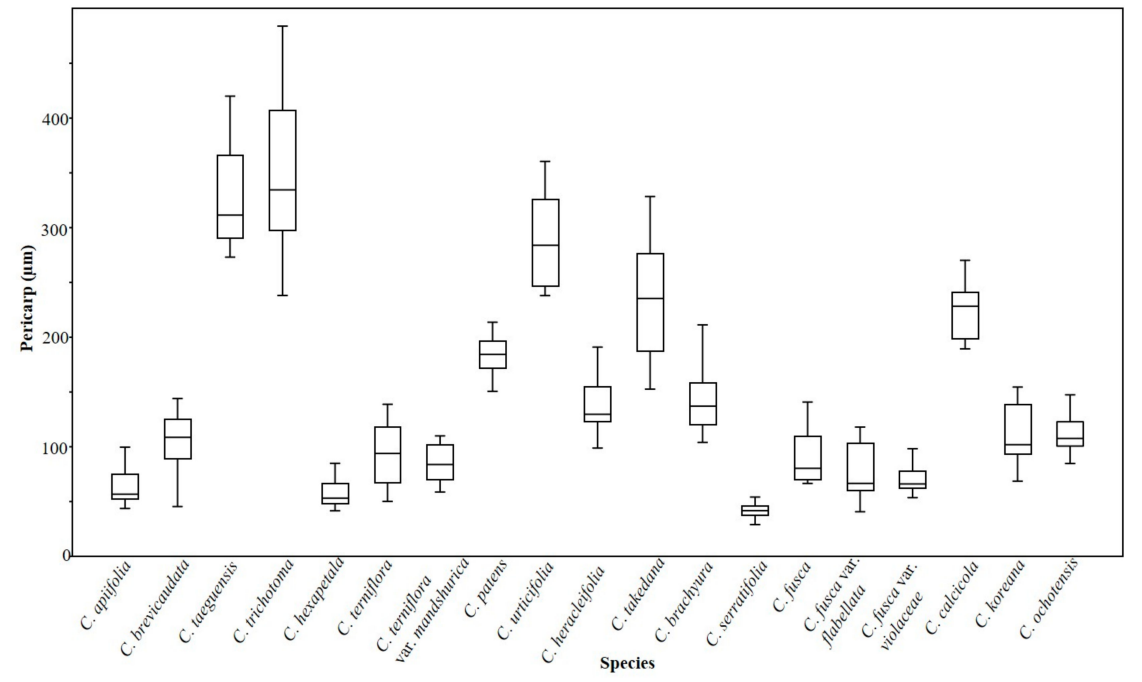

(B)

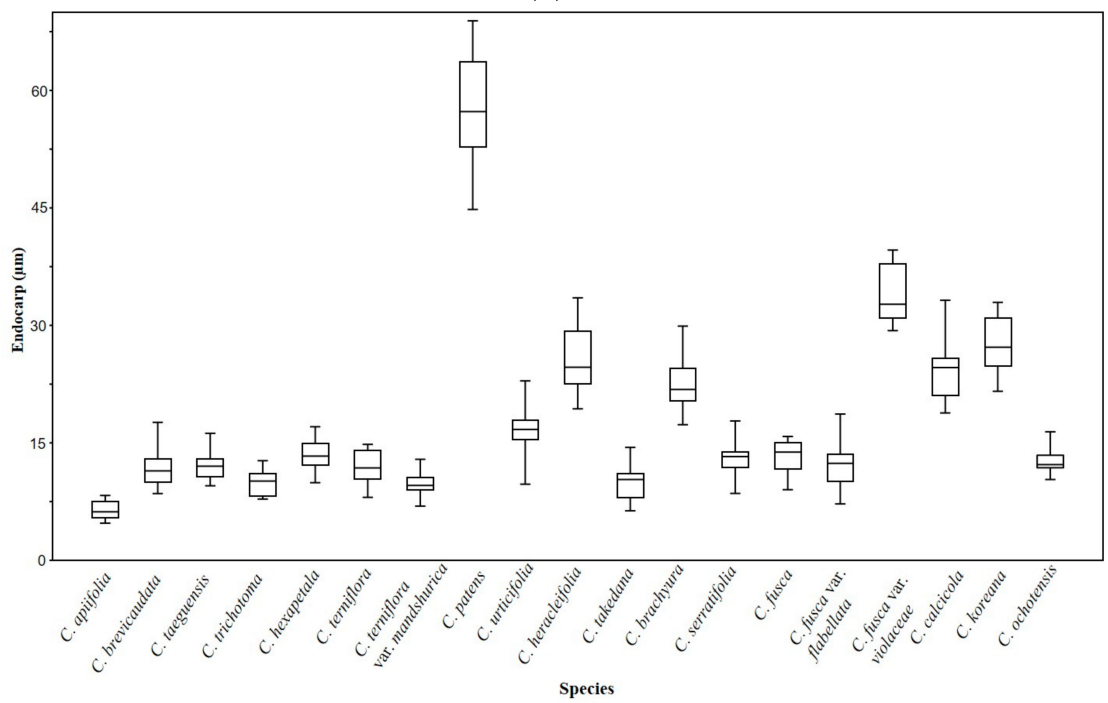

(C)

Figure 8. Normal boxplot showing style length, pericarp, and endocarp thickness of Clematis achene. (A) Style. (B) Pericarp. (C) Endocarp. 


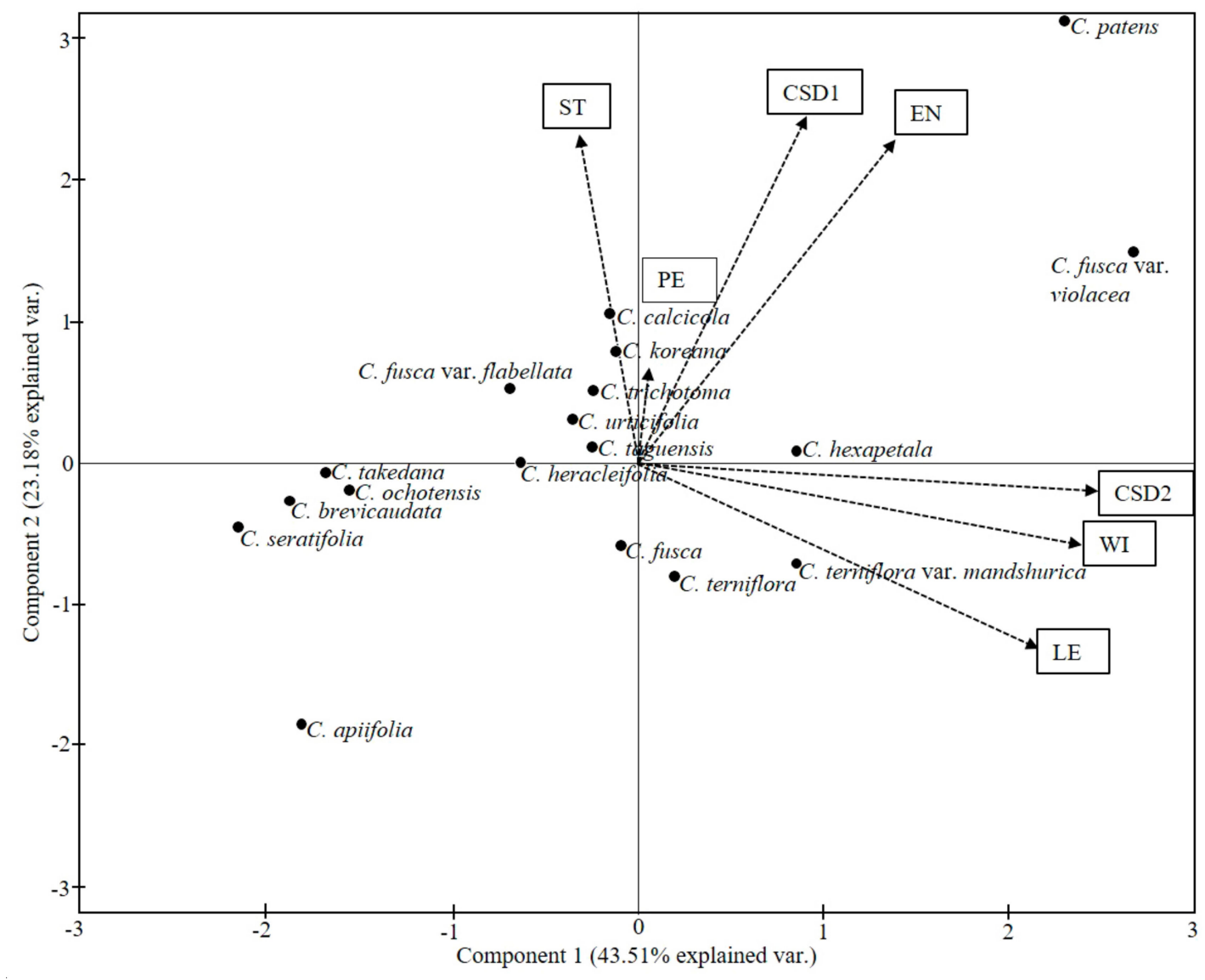

Figure 9. Principal component analysis (PCA) of seven quantitative achene characters of Clematis taxa. CSD1, cross section dimeter parallel to cotyledon; CSD2, cross section dimeter perpendicular to cotyledon; EN, thickness of endocarp; LE, length of achene; PE, thickness of pericarp; ST, length of style; WI, width. 


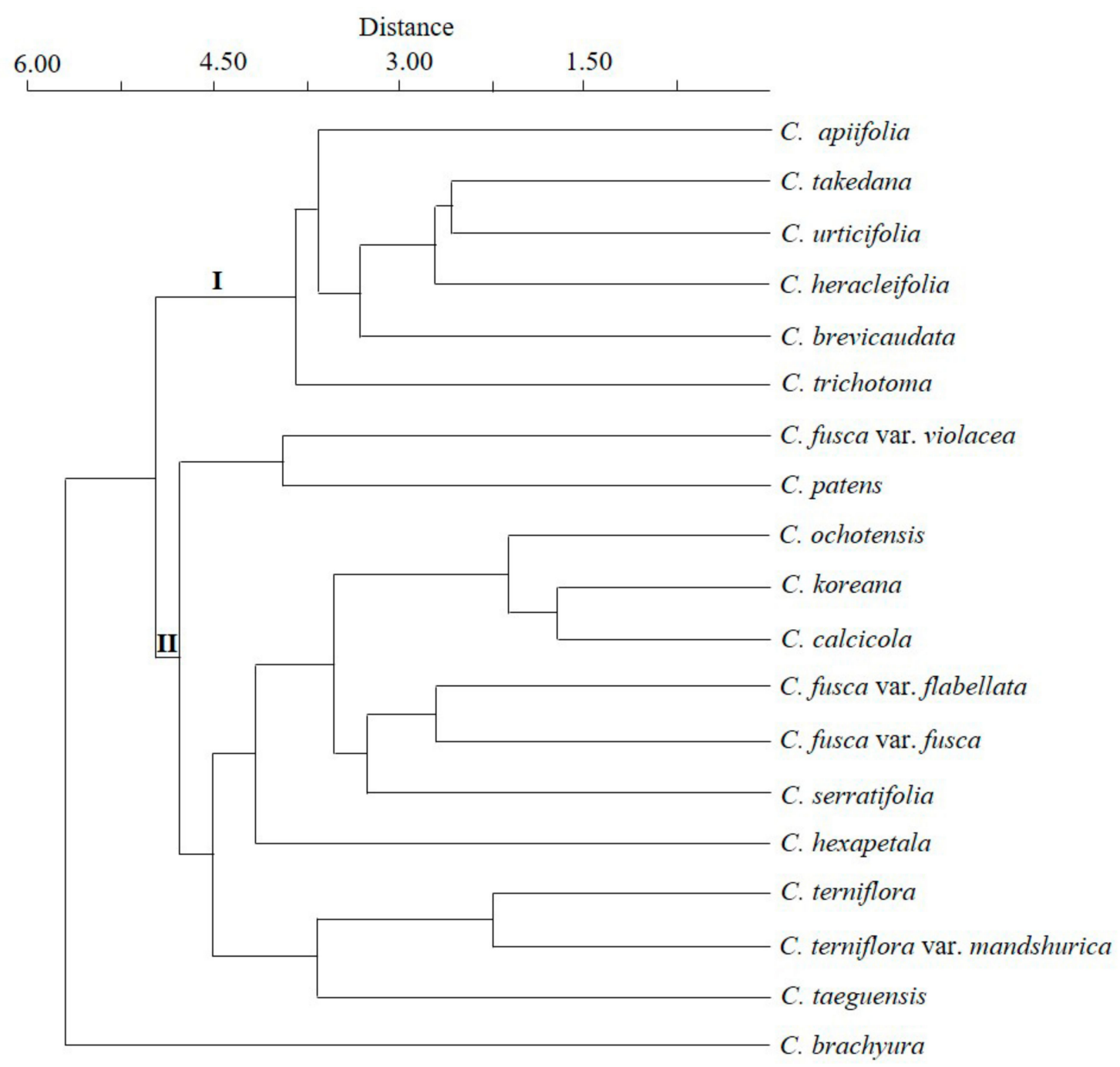

Figure 10. UPGMA cluster analysis based on achene characters of Clematis taxa.

\section{Discussion}

The achenes' morphology and anatomical features exhibited remarkable evidence for the species delimitations in Clematis as the studied species differ from each other by their achene morphology. The present study revealed that the achene size, pericarp and endocarp thickness, and length of permanent style were the quantitative characters that significantly differed between the species. Similarly, the achene indumentum, lateral wings, surface sculpture, achene outlines in cross-sections, and nature of the exocarp and endocarp cells were found to be helpful qualitative achene features for species identification. ANOVA of the quantitative variables revealed significant differences in achene length, width, style length, pericarp, and endocarp thickness among the taxa $(p<0.001)$ (Table 3$)$.

Our sampling included taxa from three out of four subgenera of Clematis proposed by Wang and Lee [3], eight sections proposed by Johnson [5], and five clades obtained by Miikeda et al. [27], Xie et al. [28], and Lehtonen et al. [28]. There was no single described species of the subgenus Cheiropsis Peterm. or other sections and clades from respective classifications recorded in Korean flora until now [10-13]. As the major classification schemes based on the morphological characters of the genus do not match one another, results from recent molecular studies $[27,28,31]$ markedly contradict such traditional infrageneric classification [1,3,4]. Since Johnson's [5,9] classifications seem to be the most congruent with contemporary molecular phylogenetic analyses of Clematis we compared our results with his classification. Although the specimens sampled represented a limited range of taxa, some of the achene features and the pericarp structure represent a valuable reference for sectional delimitations 
by Johnson [5] within Korean Clematis. For instance, the achenes of three species-C. calcicola, C. koreana, and C. ochotensis which belong to section Atragene - share comparable permanent style length, reticulate primary surface sculptures, identical anticlinal walls, and endocarp cell structures. Similarly, three species of section Tubulosae included in this study-C. heraclefolia, C. urticifolia, and C. takedana-share some key achene features such as surface sculpture, surface cell outline, periclinal and anticlinal walls, and exocarp and mesocarp structure, although cross-section of C. urticifolia exhibit narrow lateral wings and fusiform shape instead of the medium lateral wings and elliptical shape of the other two species' cross-sections. Correspondingly, three taxa of the section Viorna share equivalent pericarp thickness, striate-reticulate primary surface sculpture, polygonal surface cell outline, fusiform-shaped achenes in cross-sections, and identical mesocarp structure.

The scenario was slightly different for species of the sections Clematis and Flammula. Three species of the section Clematis, C. apiifolia, C. brevicaudata, and C. trichotoma, showed equivocally similar and dissimilar achene features. The only common feature characteristically found in these three species was the undifferentiated surface cell outline, while most of the other achene features observed in these species were shared with the species of other sections. In addition, C. trichotoma differed from C. apiifolia and C. brevicaudata by achene shape, color, and surface indumenta and had a comparatively thick mesocarp region. Similarly, C. brevicaudata had a thick layer of sclerotic endocarp and few layers of parenchymatous seed coat instead of the thin layer of lignified endocarp and degenerated seed coat found in C. apiifolia and C. trichotoma.

Four taxa of the section Flammula-C. taeguensis, C. hexapetala, C. terniflora, and C. terniflora var. mandshurica-were included and this was one of the heterogenous group in terms of achene features. Differences were observed mainly in the shape, color, surface indumentum, lateral wings, surface sculpture, periclinal wall, anticlinal wall, shape in cross-sections, thickness of the pericarp, and nature of the seed coat layers. Clematis taeguensis differs from the other three species by its sparsely hairy surface indumentum, strong style elongation, colliculate surface sculpture with a convex periclinal wall, and thick pericarp whereas $C$. hexapetala exhibits some unique achene features including medium-sized lateral wings, a fusiform achene outline in cross-section, a taniniferous exocarp, and few layers of degenerating mesocarp.

Although Moon et al. [55] described C. takedana as a newly documented species in Korea with a small population near the border of a reclaimed lake Shihwa, Hwasung-si, in Gyeonggi Province with the Korean vernacular name Ja-ju-sa-wi-jil-ppang: this species has yet to be included in The Flora of Korea [13]. Clematis takedana which is restricted to central and northern Honshu Island, Japan has morphological intermediacy between C. apiifolia (sect. Clematis) and C. stans Seibold et Zucc (sect. Tubulosae) and thus has been treated as a hybrid of these two species [60,61]. Wang and Bartholomew [6] suggested that this morphological intermediacy of C. takedana shows a transitional state between sections Clematis and Tubulosae. In the section Tubulosae, C. takedana is closely allied with C. pinnata Maxim. and both are placed in the same subsection Pinnata W. T. Wang [29,62]. Interestingly, this Chinese endemic C. pinnata has also been suggested to be a hybrid between C. bravicaudata (sect. Clematis) and C. heracleifolia (sect. Tubulosae) [63], indicating that the subsection Pinnata might be the transitional stage between sections Clematis and Tubulosae. However, recent phylogenetic study [31] denied any transitional stage and showed a very close relationship between C. bravicaudata and C. heracleifolia within a clade. Based on the achene characters we somewhat agree with the assertion that $C$. takedana is different from $C$. heracleifolia and might belong to the section Tubulosae but before confirming it as C. takedana molecular studies and investigation of the origin and distribution route of this hybrid species are necessary.

Clematis is taxonomically one of the most difficult genera in Ranunculaceae. There are major conflicts between morphological and molecular studies concerning the current infrageneric classifications $[1-5,9,26,27,29,31]$. Furthermore, current molecular studies have been unable to generate a robust phylogenetic framework and the infrageneric relationships remain highly unstable and poorly supported [26,27,29,31]. Cluster analyses based on seven quantitative and 18 qualitative achene 
features of 19 taxa have generated two large clusters connected with a basal branch representing C. brachyura (Figure 10).

Cluster I comprises six taxa, three from each of the sections Tubulosae and Clematis. Except for the position of individual taxa in the subclusters therein this cluster is apparently congruent with clade ' $C$ ' in Lehtonen et al. [31], as the section Tubulosae is nested in the section Clematis. Within the cluster C. trichotoma separated first followed by C. apiifolia and C. brevicaudata of section Clematis whereas three species of section Tubulosae nested in a separate subcluster. Here, C. heracleifolia differs from C. urticifolia and $C$. takedana by its fusiform- rather than elliptic-shaped achenes in cross-sections and relatively thick pericarp and endocarp. On the other hand, C. takedana differs from C. heracleifolia and C. urticifolia by the presence of a thick parenchymatous seed coat, with about 5-7 layers. Morphologically speaking, C. takedana is a woody vine whereas the other two species are perennial herbs $[13,55]$. Concerning the section Clematis, C. trichotoma differs from C. brevicaudata and C. apiifolia by its achene shape, color, glabrous indumentum, thick pericarp, and anticlinal walls. These three species are woody vines with 5-foliate (C. trichotoma), uni-ternate (C. apiifolia), and bi-ternate (C. brevicaudata) leaves [10,13]. This individual distribution of the taxa from the section Clematis in Cluster I indicated that achene features can be more useful for delimiting species than understanding infrageneric relationships and thus not indicative of infrageneric classification.

Cluster II comprises a morphologically heterogeneous group of taxa representing five sections included in our sampling. The most unusual grouping found in this cluster was the separation of C. hexapetala from other Flammula and rooted in the subcluster comprising the taxa of the section Atragene, Viorna, and C. serratifolia (section Meclatis). Notably, the grouping between the taxa of Viorna and C. serratifolia with C. hexapetala seems arbitrary here because-except for comparable pericarp thickness, shape in cross-section, and degenerated mesocarp, which are frequently evolved in other taxa as well-there is no single significant achene feature common within the group of these taxa. Regarding the three taxa of the section Viorna, the achenes of $C$. fusca var. violacea, which makes the separate subcluster with $C$. patens, are comparatively large, with thick and palisade like endocarp cells, low pericarp/endocarp ratios, and a degenerated exocarp. On the other hand, the achenes of C. fusca var. flabellata comprised an occasional bi-layered endocarp although few transversely divided endocarpic cells were also seen in C. fusca var. fusca and C. fusca var. violacea. It is worth mentioning here that C. fusca var. flabellata is an erect herb with uni-ternate leaves whereas C. fusca var. fusca and C. fusca var. violacea are woody vines with pinnately foliate leaves. Interestingly, in the Checklist of Vascular Plants in Korea [12], it is given a species name (Clematis flabellata Nakai); however, we cannot confirm the separate species status for C. fusca var. flabellata based on the achene morphology and anatomical evidence.

Concerning the overall similarity of $C$. serratifolia with the section Atragene, the group of these taxa shares a combination of achene features such as narrow lateral wings, reticulate surface sculpture, and degenerated exocarp. Clematis serratifolia belongs to 'Clade I' in Xie et al. [29] and 'Clade I' in Lehtonen et al. [31], whereas the section Atragene belongs to 'Clades II' in Xie et al. [29] and 'Clade H' in Lehtonen et al.'s [31] classifications. Equally, C. serratifolia differs from the species of Atragene by its thin pericarp, degenerated mesocarp, and palisade-like single-layered endocarp. We believe that variation in the endocarp structure is the key in Clematis and can be used for taxonomic discrimination, as already proved useful in other Ranunculaceae [2,8,46,51,52]. Beyond all this, C. brachyura remains at the bottom of the UPGMA phenogram and even out of the frame in the PCA plot based on the seven quantitative characters (Figure 9). According to Xie et al. [29], C. brachyura shares a clade with section Flammula. Previously, Tamura [1,2] and Wang and Lee [3] also suggested a close relationship between these two groups. The achenes of this morphologically isolated species are large, with sparsely distributed hairs, wide lateral wings, a lack of elongated style, and pustulate secondary surface sculpture. In terms of general morphology, C. brachyura shares its erect herbaceous nature, identical inflorescence, and floral structure with $C$. terniflora and C. hexapetala of the section Flammula but differs by its short style and broadly winged achenes; it is placed under the monotypic section Pterocarpa [2-4,11]. 


\section{Conclusions}

In this study, achene indumentum, surface sculpture, and pericarp and endocarp structure proved to be the most useful achene features for characterizing Clematis taxa. The results also indicated that taxa of section Atragene and Tubulosae displayed similarity in certain key achene features; however, the number of taxa sampled was very low for these sections, and thus any interpretation made on this basis is arbitrary. Further studies considering as many taxa as possible from different sections will certainly be helpful for resolving the taxonomy of the genus. The understanding from this study is that achene morphology alone as a single source of characters, cannot be expected to elucidate the problematic infrageneric relationships but a thorough analysis of current and other morphological, as well as molecular data, will be helpful to accomplish this. Our results, however, demonstrated that achene features can contribute valuable information and could be used as descriptive and/or diagnostic characters of the Clematis species.

Supplementary Materials: The following are available online at http://www.mdpi.com/2223-7747/9/10/1279/s1, File S1: Quantitative measurement of achene features of Clematis species, File S2: Character and character states of achenes of Clematis.

Author Contributions: B.G. and B.K.P. conceived the study. B.G. conducted most experiment, D.C.S. and B.K.P. help in statistical analysis. B.G. wrote the manuscript, D.C.S. and S.-H.O. edited the manuscript. All authors have read and approved the manuscript.

Funding: This study including APC was financially supported by the project "Silvics of Korea (KNA1-1-18, 15-3)".

Acknowledgments: Authors thank anonymous reviewers for their insightful comments and suggestions to the early version of this manuscript.

Conflicts of Interest: The authors declare that they have no conflict of interest.

\section{References}

1. Tamura, M.A. Classification of genus Clematis. Acta Phytotaxon. Geobot. 1987, 38, 33-44.

2. Tamura, M. Angiospermae: Ordnung Ranunculales. Fam. Ranunculaceae. In Die Natürlichen Pflanzenfamilien; Hiepko, P., Ed.; Duncker and Humblot: Berlin, Germany, 1995; Volume 17, pp. 324-349.

3. Wang, W.T.; Li, L.Q. A new system of classification of the genus Clematis (Ranunculaceae). Acta Phytotaxon. Sin. 2005, 43, 431-488.

4. Grey-Wilson, C. Clematis the Genus: A Comprehensive Guide for Gardeners, Horticulturists and Botanists; Timber Press: Portland, OR, USA, 2000.

5. Johnson, M. The Genus Clematis; Magnus Johnson Plantskola: Stockholm, Sweden, 2001.

6. Wang, W.T.; Bartholomew, B. Clematis . In Flora of China; Wu, Z.Y., Raven, P., Eds.; Science Press: Beijing, China; Missouri Botanical Garden Press: St. Louis, MO, USA, 2001; Volume 6.

7. Ellitto, A.C. Systematics of Clematis in Nepal, the Evolution of Tribe Anemoneae DC. (Ranunculaceae) and Phylogeography and Dynamics of Speciation in the Himalaya. Ph.D. Thesis, University of Edinburgh, Edinburgh, UK, 2016.

8. Prantl, K. Beitrage zur Morphologie und Systematik der Ranunculaceen. Bot. Jahrb. Syst. Pflanzengesch. Pflanzengeogr. 1888, 9, 225-273.

9. Johnson, M. Slaktet Klematis; Magnus Johnson Plantskola: Stockholm, Sweden, 1997.

10. Lee, Y.N. New Flora of Korea; Kyo-Hak Publishing Co. Ltd.: Seoul, Korea, 2007; Volume I.

11. Chang, C.S.; Kim, H.; Chang, K.S. Illustrated Encyclopedia of Fauna and Flora of Korea. Woody Plants; Ministry of Education Science and Technology: Seoul, Korea, 2011; Volume 43, 511p.

12. Chang, K.S.; Son, D.C.; Lee, D.-H.; Choi, K.; Oh, S.H. Checklist of Vascular Plants in Korea; Korea National Arboretum: Pocheon-Si, Korea, 2017; 1000p.

13. Kim, J.S. Clematis, L. In Flora of Korea. Magnoliidae; Flora of Korea Editorial Committee and the National Institute of Biological: Gyeongsangbuk-do, Korea, 2017; Volume 2a, pp. 69-76.

14. Tamura, M. Systema clematidis asiae orientalis. Sci. Rep. 1955, 4, 43-55.

15. Tamura, M. Ranunculaceae. In The Families and Genera of Vascular Plants; Kubitzki, K., Rohwer, J.G., Bittrich, V., Eds.; Springer: Berlin/Heidelberg, Germany, 1993; Volume 2, pp. 563-583. 
16. Tobe, H. Morphological studies on the genus Clematis Linn. I. Pollen grains. Sci. Rep. Tohoku Univ. Fourth Ser. Biol. 1974, 37, 47-53.

17. Tobe, H. Morphological studies on the genus Clematis Linn. V. vascular anatomy of the calyx region in four-sepaled flowers. Bot. Mag. Tokyo 1980, 93, 39-54. [CrossRef]

18. Tobe, H. Morphological studies on the genus Clematis Linn. VI. Vascular anatomy of the androecial and gynoecial regions of the floral receptacle. Bot. Mag. Tokyo. 1980, 93, 125-133. [CrossRef]

19. Tobe, H. Morphological studies on the genus Clematis Linn. VII. Reinvestigation of Clematis williamsii A. Gray and proposal of its taxonomic transfer to Clematopsis. Bot. Mag. Tokyo. 1980, 93, 135-148. [CrossRef]

20. Essig, F. Seedling morphology in Clematis (Ranunculaceae) and its taxonomic implications. Sida 1991, 14, 377-390.

21. Zhang, Y.L. Chromosome studies on 7 species of Clematis in China. J. Wuhan Bot. Res. 1991, 9, 107-113.

22. Snoeijer, W. A suggested classification for the genus Clematis. Clematis 1992, 7-20.

23. Yano, Y. Pollen grain morphology in Clematis (Ranunculaceae). Clematis 1993, 42-43.

24. Yang, T.Y.; Moore, D.M. A revision of the Viorna group of species (section Viorna sensu Prantl) in the genus Clematis (Ranunculaceae). Syst. Geogr. Plant. 1999, 68, 281-303. [CrossRef]

25. Shi, J.H.; Li, L.Q. Leaf epidermal feature in Clematis (Ranunculaceae) with reference to its systematic significance. Acta Bot. Sin. 2003, 45, 257-268.

26. Miikeda, O.; Koga, S.; Handa, T.; Yukawa, T. Subgeneric relationships in Clematis (Ranunculaceae) by DNA sequences. In Taxonomy of Cultivated Plants: Third International Symposium; Andrews, S., Leslie, A., Alexander, C., Eds.; Royal Botanic Gardens Kew: London, UK, 1999; pp. 355-358.

27. Miikeda, O.; Kita, K.; Handa, T.; Yukawa, T. Phylogenetic relationships of Clematis (Ranunculaceae) based on chloroplast and nuclear DNA sequences. Bot. J. Linn. Soc. 2006, 152, 153-168. [CrossRef]

28. Slomba, J.M.; Garey, J.R.; Essig, F.B. The actin I intron-a phylogenetically informative DNA region in Clematis (Ranunculaceae). Sida 2004, 21, 879-886.

29. Xie, L.; Wen, J.; Li, L.Q. Phylogenetic analyses of Clematis (Ranunculaceae) based on sequences of nuclear ribosomal ITS and three plastid regions. Syst Bot. 2011, 36, 907-992. [CrossRef]

30. Jiang, N.; Zhou, Z.; Yang, J.B.; Zhang, S.D.; Guan, K.Y.; Tan, Y.H.; Yu, W.B. Phylogenetic reassessment of tribe Anemoneae (Ranunculaceae): Non-monophyly of Anemone s.l. revealed by plastid datasets. PLoS ONE 2017, 12, e0174792. [CrossRef]

31. Lehtonen, S.; Christenhusz, M.J.M.; Falck, D. Sensitive phylogenetics of Clematis and its position in Ranunculaceae. Bot. J. Linn. Soc. 2016, 182, 825-867. [CrossRef]

32. Fukuhara, T. Seed and funicle morphology of Fumariaceae-Fumarioideae: Systematic implications and evolutionary patterns. Int. J. Plant Sci. 1999, 160, 151-180. [CrossRef]

33. Juan, R.; Pastor, J.; Fernandez, I. SEM and light microscope observations on fruit and seeds in Scrophulariaceae from Southwest Spain and their systematic significance. Ann. Bot. 2000, 86, 323-338. [CrossRef]

34. Moro, F.V.; Pinto, A.C.R.; Dos Santos, J.M.; Filho, C.F.D. A scanning electron microscopy study of post-seminal development in Angelonia salicarii folia Bonpl. (Scrophulariaceae). Ann. Bot. 2001, 88, 499-506. [CrossRef]

35. Ozcan, T. SEM observations on petals and fruits of some Turkish endemic Bupleurum, L. (Umbelliferae) species. Bot. J. Linn. Soc. 2002, 138, 441-449. [CrossRef]

36. Xu, F. Sclerotesta morphology and its systematic implications in Magnoliaceous seeds. Bot. J. Linn. Soc. 2003, 142, 407-424. [CrossRef]

37. Zhang, Z.Y.; Yang, D.Z.; Lu, A.M.; Knapp, S. Seed morphology of the tribe Hyoscyameae (Solanaceae). Taxon 2005, 54, 71-83. [CrossRef]

38. Amini, E.; Zarre, S.; Assadi, M. Seed micro-morphology and its systematic significance in Gypsophila (Caryophyllaceae) and allied genera. Nor. J. Bot. 2011, 29, 660-669. [CrossRef]

39. Ghimire, B.; Jeong, M.J.; Choi, G.E.; Lee, H.; Suh, G.K.; Heo, K.; Ku, J.J. Seed morphology of the subfamily Helleboroideae (Ranunculaceae) and its systematic implication. Flora 2015, 216, 6-25. [CrossRef]

40. Ghimire, B.; Jeong, M.J.; Lee, K.M.; Heo, K.; Lee, C.H.; Suh, G.U. Achene morphology of Saussurea species (Asteraceae, Cardueae) in Korea and its systematic implications. Bot. J. Linn. Soc. 2016, 181, 692-710. [CrossRef]

41. Ghimire, B.; Lee, H.; Choi, G.E.; Jeong, M.J.; Lee, C.H.; Suh, G.U.; Heo, K.; Son, S.W. Seed morphology of 12 taxa of the genus Thalictrum, L. (Thalictroideae, Ranunculaceae) and its systematic implication. Phytotaxa 2016, 283, 271-285. [CrossRef] 
42. Cappelletti, E.M.; Poldini, L. Seed morphology in some European aconites (Aconitum, Ranunculaceae). Plant Syst. Evol. 1984, 145, 193-201. [CrossRef]

43. Chaudhary, R.P.; Trifonova, V.I. Morphology of fruit and comparative anatomy of pericarp and seed coat in the Nepal species of the genus Anemone (Ranunculaceae). Bot. Z. 1988, 73, 803-817.

44. Constantinidis, T.; Psaras, G.K.; Kamari, G. Seed morphology in relation to infrageneric classification of Consolida (DC.) Gray (Ranunculaceae). Flora 2001, 196, 81-100. [CrossRef]

45. Dadandi, M.Y.; Kökdil, G.; İlçim, A.; Ozbilgin, B. Seed macro and micro morphology of the selected Nigella (Ranunculaceae) taxa from Turkey and their systematic significance. Biologia 2009, 64, 261-270. [CrossRef]

46. Heiss, A.G.; Kropf, M.; Sontag, S.; Weber, A. Seed morphology of Nigella s.l. (Ranunculaceae): Identification, diagnostic traits, and their potential phylogenetic relevance. Int. J. Plant Sci. 2011, 172, 267-284. [CrossRef]

47. Ilaraslan, H.; Ilarslan, R.; Blanche, C. Seed morphology of genus Delphinium, L. (Ranunculaceae) in Turkey. Collect. Bot. 1997, 23, 79-95. [CrossRef]

48. Karcz, J.; Tomzcok, J. Microstructural features of seeds surface in 6 Species of the genus Nigella, L. (Ranunculaceae). Acta Biol. Siles. 1987, 7, 111-125.

49. Luo, Y.; Zhang, F.M.; Yang, Q.E. Phylogeny of Aconitum subgenus Aconitum (Ranunculaceae) inferred from ITS sequences. Plant Syst. Evol. 2005, 252, 11-25. [CrossRef]

50. Wang, W.; Lu, A.M.; Ren, Y.; Endress, M.E.; Chen, Z.D. Phylogeny and classification of Ranunculales: Evidence from four molecular loci and morphological data. Perspect. Plant Ecol. Evol. Syst. 2009, 11, 81-110. [CrossRef]

51. Ziman, S.N.; Bulakh, E.V.; Kadota, Y.; Keener, C.S. Modern view on the taxonomy of the genus Anemone, L. sensu stricto (Ranunculaceae). J. Jap. Bot. 2008, 83, 127-155.

52. Maciejewska-Rutkowska, I.; Antkowska, W. Taxonomic utility of achene morphology and anatomy in Anemone, L. (Ranunculaceae) species. Acta Biol. Carcov. Bot. 2013, 55, 29-36.

53. Nakai, T. Synoptical sketch of the Korean Flora. Bull. Natl. Sci. Mus. 1952, 31, 1-152.

54. Lee, C.B. Illustrated Woody Plants of Korea; Forest Experiment Station: Seoul, Korea, 1967; pp. 1-384.

55. Moon, A.R.; Han, J.E.; Lee, B.Y.; Park, J.M.; Jang, C. An unrecorded species of genus Clematis (Ranunculaceae) from Korea. J. Asia Pac. Biodivers. 2013, 6, 415-418. [CrossRef]

56. Korea National Arboretum and the Plant Taxonomic Society of Korea. A Synonymic List of Vascular Plants in Korea; Korea National Arboretum: Pocheon, Korea, 2007. (In Korean)

57. Lee, Y.N. New taxa of Korean flora (4). Korean J. Bot. 1982, 25, 175-180.

58. World Flora Online (WFO). WFO: Clematis taeguensis Y.N.Lee. 2020. Available online: http://www. worldfloraonline.org/taxon/wfo-0000610734 (accessed on 20 August 2020).

59. Hammer, Ø.; Harper, D.A.T.; Ryan, P.D. PAST: Paleontological Statistics Software Package for Education and Data Analysis. Palaeontol. Electron. 2001, 4, 9.

60. Makino, T. Observations on the flora of Japan. Bot. Mag. 1907, 21, 86-88. [CrossRef]

61. Ohwi, J. Clematis. In Flora of Japan; Smithsonian Institution: Washington, DC, USA, 1965; pp. 440-442.

62. Wang, W.T.; Lei, X. A revision of Clematis sect. Tubulosae (Ranunculaceae). Acta Phytotaxon. Sin. 2007, 45, 425-457. [CrossRef]

63. Shi, J.H. A Preliminary Study of the Hybrid Origin of Clematis pinnata Maxim. (Ranunculaceae). Master's Dissertation, Beijing Institute of Botany, Chinese Academy of Sciences, Beijing, China, 2003.

(C) 2020 by the authors. Licensee MDPI, Basel, Switzerland. This article is an open access article distributed under the terms and conditions of the Creative Commons Attribution (CC BY) license (http://creativecommons.org/licenses/by/4.0/). 